\title{
[INFORME BIBLIOGRÁFICO]
}

\author{
Relación de las fuentes de la estética \\ británica del siglo XVIII
}

\author{
JORGE V. ARREGUI Y PABLO ARNAU
}

LA PRESENTE RELACIÓN de Fuentes de la estética británica del siglo XVIII pretende recoger la totalidad de los escritos sobre estética publicados en Gran Bretaña desde 1700 hasta 1799. Se han omitido, por tanto, los trabajos anteriores o posteriores a esas fechas, incluso si se mencionan otras obras -o ediciones- de esos mismos autores. Sin embargo, se ha procurado consignar todas las ediciones realizadas durante el siglo XVIII en Gran Bretaña (aunque la relación tiene lagunas), así como sus traducciones aparecidas en otros países durante ese mismo periodo, pues esos datos resultan muy significativos de su difusión.

A la hora de confeccionar esta relación de fuentes de la estética ilustrada británica, se ha usado un criterio relativamente amplio de qué cuenta como estética. Por una parte, la estrecha vinculación entre ética y estética, propia de las discusiones británicas dieciochescas, obligaba a incluir en el listado algunos trabajos que, aunque versaban dircctamente sobre ética, incluían páginas muy relevantes para la estética del periodo; por otra, parecía necesario dar razón también de al gunos textos de *teoría de las artes» sin los que no cabe hacerse cargo del pensamiento estético del XVIII.

Como se trataba de hacer una relación de fuentes lo más útil posible, se ha dado cuenta también tanto de las ediciones más recientes y accesibles en el mercado de estas fuentes, sobre todo si se trataba de cdiciones facsímiles o de reimpresiones, como de las traducciones castellanas existentes. Hemos trabajado fundamentalmente con los catálogos publicados por la British Library ${ }^{1}$ y The Bibliographical Society2 y nos han resultado de especial utilidad los trabajos previos de J. W. Draper, T. E. Jessop y L.

1 The Eighteenth Century Short Title Catalogue. Londres: The British Library, 1990.

2 A Short-Title Catalogue of Books Printed in England, Scoiland and Ireland. 1475-1640, Londres: The Bibliographical Society, 1986. 
Formigari ${ }^{3}$, además de la bibliografía recogida en las obras de S. H. Monk, L. A. Elioseff, P. Gay, J. Engell y P. de Bolla4.

ABBOTT, Charles, An Essay on the Use and Abuse of Satire. ¿Oxford 1786 ?

ADDISON, Joseph, The Works of the Right Honourable Joseph Addison. 4 vols. Printed for Jacob Tonson. Edited by Thomas Tickell, London, 1721.

-The Poetical Works of the Right Honourable Joseph Addison. Printed by Robert Urie, Glasgow 1750.

Idem. 1760.

Idem. Printed for J. Balfour \& W. Creech, Edinburgh, 1773.

-Miscellaneous Works, in Verse and Prose, of the Late Right Honourable Joseph Addison. 3 vols. Printed for J. \& R. Tonson, \& S. Draper, London, 1736.

Idem 1746, 1753, 1765, 1776.

-Critical Essays from the Spectator. Ed. de R. Steele, Clarendon Press, Oxford 1970 .

-Addison and Steele, the Critical Heritage. Ed. de E. A. Bloom y L. D. Bloom, Routledge and Kegan Paul, London, 1980.

-Criticisms on Paradise Lost. Edición, introducción y notas de A. S. Cook, Phaeton Press, New York, 1968.

-Essays in Criticism and Literary Theory. Ed. de J. Loftis, AHM Pu. Co., Northbrook, III. 1975.

-The Freeholder. Edición, introducción y notas de J. Leheny, Clarendon Press, Oxford 1979.

-The Letters of Joseph Addison. Ed. de W. Graham, Scholarly Press, St. Clair Schores, Michigan 1976.

-The Miscellaneous Works of Joseph Addison. Ed. de A. C. Guthkelch, Scholarly Press, St. Clair Schores, Michigan 1978.

- Los placeres de la imaginación, traducción de J. L. Munáriz, Oficina de D. Antonio Cruzado, Madrid 1798-1801. Reproducida en Los placeres de la imaginación y otros ensayos de The Spectator. Visor, Madrid 1991.

3 J. W. Draper, Eighteenth Century English Aesthetics. A Bibliography. Heildelberg 1931; T. E. Jessop, A Bibliography of D. Hume and of the Scottish Philosophy. Londres: A. Brown \& Sons, 1938 y L. Formigari, Studi sull' esterica dell' empirismo inglese. Roma: Centro di Ricerce di Storia della Storiografía, 1971.

4 S. H. Monk, The Sublime: A Study of Critical Theories in Eighteenth-Century England. Ann Arbor 1960; L. A. Elioseff, The Cultural Milieu of Addison's Literay Criticism. Austin: University of Texas Press, 1963; P. Gay. The Enlightenment: an Interpretation. Vol. 2: The Science of Freedom. Londres: Weidenfeld and Nicholson, 1970; J. Engell, The Creative Imagination. Enlightenment to Romanticism. Cambridge Mass.: Harvard University Press, 1981 y P. de Bolla, The Discourse of the Sublime. Readings in History, Aesthetics and the Subject. Oxford: Blackwell, 1989. 
AIKIN, John, An Essay on the Application of Natural History to Poetry. Printed by W. Eyres for J. Johnson, London, 1777. Reimpresión en Garland Pu. Co., New York, 1970.

-Essays on Song Writing. London, 1722 (?).

AIKIN, John y BARBAULD, A. L., Evenings at Home; or, the Juvenile Budget Oposite. Consisting of a Variety of Miscellaneous Pieces. Printed for J. Johnson, London, $1792-6,6$ vols.

Varias ediciones en London y Filadelfia.

AKENSIDE, Mark, The Pleasures of Imagination. A Poem. Three Books. Printed by R. Dodsley, London, 1744.

Idem. $5^{\mathrm{a}}$ ed. 1754.

Idem. $6^{a}$ ed. 1763.

Idem. By Dr. Aikinside. Printed for William C. in Leith, Edinburgh, 1768.

Idem. Printed for R. Dodsley, London, 1769.

Idem. Printed by R. \& A. Foulis, Glasgow 1771, 1775 y 1777.

- Traducción francesa en Pissot, París 1759.

- Poems. Printed by W. Bowyer \& J. Nichols, Sold by J. Dodsley. Edited by the Right Hon. J. Dyson, London, 1772.

-Odes on Several Subjects. Printed for R. Dodsley. Sold by M. Cooper, London, 1745.

-The Poetical Manuscripts of Mark Akenside in the Ralph M. Williams Collection, Amherst College Library. Reimpresión con una introducción de R. C. Dix, Amherst College Press, Amherst (Mass.), 1988.

ALISON, Archibald, Essays on the Nature and Principles of Taste. Printed for Messrs. P. Byrne, J. Moore, Grueber \& M'Allister, W. Jones \& R. White, Dublin, 1790. Reimpresión en G. Olms, Hildesheim 1968.

-Über den Geschmack, K. H. Heidenreich, Leipzig 1792.

ALLEN, G, Some Occasional Thoughts on Genius, with an Apology for so Long Deferring the Publishing of Observations in the Art of Painting. Printed for the Author, London, 1750.

ARBUCKLE, James, Stuff a Poem. Printed in the year, Glasgow 1717.

Idem. Printed by Mr. J. M. Euen and Company for the Author, and to be Sold by Mr. J. M. Euen and by the Booksellers in Glasgow, Edinburgh, 1719.

-A Collection of Letters and Essays on Several Subjects, Lately Publish'd in Dublin, Journal. 2 vols. Printed by J. Darby \& T. Browne. Sold by J. Osborn \& T. Longman, \& J. Gray, London, 1729. También by Messieurs Smith and Bruce, G. Grierson, G. Ewin \& W. Smith, Dublin, 1729. Reimpresión en Garland Pu. Co., New York, 1970, 2 vols.

-Hibernicus's Letters: or, a Philosophical Miscellany. 2 vols, $2^{2}$ ed. London, 1734.

ARMSTRONG, J., Taste: An Epistle to a Young Critic en Miscellanies. Printed for T. Cadell, London, 1753.

AVISON, Charles, An Essay on Musical Expression. C. Davis, London, 1752.

Idem. With A Reply to the Author of Remarks on the Essay on Musical Expression. London, 1753.

Idem. Printed for L. Davis, London, 1775. 
BAILLIE, John, Essay on the Sublime. Printed for R. Dodsley and Sold by M. Cooper, London, 1747,41 págs.

BALFOUR, James, A Delineation of Nature and Obligation of Morality. Printed by Hamilton, Balfour, \& Neill, Edinburgh, 1753.

Idem. $2^{\mathrm{a}}$. ed. by Hamilton \& Balfour, Edinburgh, 1763.

BALGUY, John, A Letter to a Deist, Concerning the Beauty and Excellency of Moral Virtue. Printed for J. Permberton, London, 1726.

Idem. $2^{a}$ ed. 1730.

-Foundation on Moral Goodness: or, a Further Inquiry into the Original of our Idea of Virtue. 1728. $3^{\mathrm{a}}$ ed. Printed for J. Permberton, London, 1733.

-The Second Part of the Foundation of Moral Goodness. Printed for J. Permberton, London, 1729. Reimpresión de ambas partes en Garland Pu. Co., New York, 1976, 102 págs.

BANKS, John, Essay on Design and Beauty, Edinburgh, 1739.

BARDWELL. Thomas, Practice of Painting and Perspective. Printed by S. Richardson, London, 1756.

Idem. 1782.

Idem. Printed for B. \& J. White. London, 1795.

BARNES, Thomas, On the Nature and Essential Character of Poetry as Distinguished from Prose. Memoirs of Manchester Literary and Philosophical Society, I, 1785, Dublin, 1791.

BARRY, James, An Account of a Series of Pictures. Printed by W. Adlardd and Sold by T. Cadell \& J. Walter 1783.

- An Inquiry into the Real and Imaginary Obstructions to the Adquisition of the Arts in England. Printed for T. Becquer, London, 1775.

-A Letter to the Dilettanti Society Respecting...Matters Essentially Necessary for the Improvment of Public Taste. Printed for J. Walker, London, 1798.

Idem. 1799.

-A Letter to the Right Honorable the President, the Vice-presidents and the Members of the Society for Encouragement of Arts. Printed by T. Davison, London, 1793.

BAXTER, Andrew, Enquiry into the Nature of the Human Soul. Printed by James Bettenham for the Author, London, y Edinburgh, 1733.

Idem. $3^{a}$ ed. Printed by J. Bettenham for S. Millar, London, 1745.

-An Appendix to the First Part of the Enquiry into the Nature of the Human Soul. Printed for the Author, London, 1750.

BAYLY, Anselm, A Practical Treatise on Singing and Playing. London, 1711.

-The Alliance of Music, Poetry and Oratory. Printed for J. Stockdale, London, 1789. Reimpresión en Garland Pu. Co., New York, 1970, 384 págs.

-Essays, Philosophical, Historical, and Literary. 1799. Reimpresión en Garland Pu. Co., New York, 1971, 2 vols.

BEATTIE, James, The Judgement of Paris. A Poem. Printed for T. Becket \& P. A. De Hondt en London, y J. Balfour en Edinburgh, 1765. 
-The Minstrel; or, the Progress of Genius. A Poem. Book the First. Printed for E. \& C. Dilly en London, \& A. Kincaid \& J. Bell en Edinburgh, 1771.

Idem. $2^{a}$ ed. $1771,1772,1774,1775$.

Idem. In two Books. Printed by James Willliams, Dublin, 1775, 1779.

Idem. A new edition. Printed for Charles Dilly en London, y W. Creech en Edinburgh, 1784

Idem. A new edition. Printed for Charles Dilly, London, 1795.

Idem. Printed by T. Gillet, for C. Dilly en London, y W. Creech en Edinburgh, 1797. Idem. A new edition. Printed by T. Gillet for C. Dilly, 1799.

Idem. The Second Book. Printed by E. \& Ch. Dilly en London, y William Creech en Edinburgh, 1774.

Idem. $2^{\mathrm{a}}$ ed. 1774.

-Essays on Poetry and Music, as They Affect the Mind. Edinburgh, 1776.

Idem. Printed for E. \& Ch. Dilly en London, y W. Creech en Edinburgh, 1778.

Idem. $3^{a}$ ed. corrected. Printed for E. \& Ch. Dilly en London, y W. Creech en Edinburgh, 1779.

-Dissertations Moral and Critical. On Memory and Imagination. On Dreaming. The Theory of Language. On Fable and Romance. On the Attachments of Kindred. Illustrations on Sublimity. Printed for W. Straham en London, y T. Cadell \& W. Creech en Edinburgh, 1783.

Idem. 2 vols. Printed for Mess. Exshaw, Walker, Beatty, White, Birne, Cash and Mckenzie, Dublin, 1783.

-Traducción al castellano en Espiritu de los mejores diarios literarios que se publican en Europa, nn. del 204 al 212, octubre, noviembre y diciembre de 1789.

- The Theory of Language. A new edition. Printed for A. Straham, T. Cadell en London, y W. Creech en Edinburgh, 1788.

- Essai sur la Poésie et la Musique. París y Milán 1798.

-Neue philos. Versuche. Trad. de Meiners, Leipzig 1779.

-The Philosophical and Critical Works. G. Olms, Hildesheim 1974.

BECKFORD, William, Biographical Memoirs of Extraordinary Painters. Printed for J. Robson, London, 1780.

-Modern Novel Writing; or the Elegant Enthusiast. Printed for G. G. \& J. Robinson, London, 1796.

BEDFORD, A., The Evil and Danger of Stage-plays. Printed and Sold by W. Bonny \& H. Mortlock, Bristol y London, 1706.

-The Great Abuse of Music. Printed for J. H. by J. Wyatt, London, 1711.

-The Excelency of Divine Music. Printed by W. Pearson and Sold by C. Rivington, London, 1733.

BELL, Henry, An Historical Essay on the Original of Painting. Printed by J. Worral, London, 1728.

Idem 1730.

BELSHAM, William, Essays Philosophical, Historical and Literarys. Printed for C. Dilly, London, 1789. 
Idem. 2 vols. Printed for G. G. \& J. Robinson, London, 1799.

BENSON, William, Letters Concerning Poetical Translations and Virgil's and Milton's Art of Verse. Printed for J. Roberts, London, 1739.

BERINGTON, Joseph, Miscellaneous Dissertations... on the Origin and Antiquity of Masquerades. London, 1751.

BERKELEY, George5, Berkeley's Philosophical Writings, ed. de D. M. Armstrong, New York, 1965.

BLACKMORE, Sir Richard, Essays. Printed for E. Curll \& J. Pemberton, London, 1716-7. Reimpresión en Garland Pu. Co., New York, 1971, 448 págs.

-An Essay upon Wit. Introducción de R. C. Boys, Augustan Reprint Society, 1946.

-The Nature of Man. A Poem. In Three Books. Printed for S. Buckley, London, 1711. Idem. Printed for J. Clark \& A. Dodd, London, 1720.

BLACKWALL, Anthony, An Introduction to the Classics. Printed for G. Mortlock, H.

Clements \& W. Cantrell, Derby y London, 1718.

Idem. 1719, 1725, $1728,1737$.

Idem. Printed for J. \& J. Rivington. London, 1746.

-The Sacred Classics Defended and Illustrated. Printed for J. Bettenham \& W. Catrell, London, y Derby 1725.

Idem. 1727.

Idem. Printed for Ch. Rivington. London, 1731, 1737.

Idem. Printed for J. Walthoe, London, 1741.

-Rhetorik and Poetry, Printed by L. Thomas \& E. T. Andrews, Boston 1796.

BLACKWELL, Thomas, Enquiry into the Life and Writings of Homer. London, 1735.

Reimpresión en Garland Pu. Co., New York, 1970, 335 págs.

Idem. $2^{2}$ ed. 1736.

Idem. $4^{\mathrm{a}}$ ed. Printed for R. Urie, Glasgow 1761.

-Letters Concerning Mithology. Printed in the year, London, 1748.

Idem. Printed for E. Dilly, London, 1757.

BLAIR, Hugh, A Critical Dissertation on the Poems of Ossian, the Son of Fingal. Appended to The poems of Ossian. Printed for T. Becket \& P. A. De Hondt, London, 1763,75 págs.

Idem. $2^{a}$. ed. 1765. Reimpresión en Garland Pu. Co., New York, 1970.

Idem. $3^{\text {a }}$. ed. Printed for Peter Wilson, London, 1765. -Lectures on Rhetoric and Belles Lettres. Printed for W. Strahan \& T. Cadell en London,
y W. Creech en Edinburgh, 1783.

Idem. 3 vols. Printed for Messrs. Whitestone, Colles, Burnet, Moncrieffe, Gilbert et al. en Dublin, 1783.

Idem. Printed and Sold by R. Aitken, Filadelfia 1784.

5 T. E. Jessop, A Bibliography of G. Berkeley, La Haya: M. Nijhoff, 1973. Vid. también G. Keynes, A Bibliography of George Berkeley. Oxford: Clarendon Press, 1976. 
Idem. $2^{a}$ ed. London, 1785, 1787. Reimpresión en Garland Pu. Co., New York, 1970, 3 vols.

Idem. 3 vols. Printed by J. J. Tourneisen, Basilea 1788.

Idem. $4^{\mathrm{a}}$ ed. London, 1790, 1793, 1796.

-Lectures on Rethoric and Belles Lettres. Abridgements. Printed for R. Moncrieffe, Dublin, 1784.

Idem. $2^{a}$. ed. Printed for J. Murray, London, 1785, 1787.

-Sentimental Beauties and Moral Delineations. Printed at the Logographic Press, for John Wallis, London, 1786.

Idem. Selected with a View to Refine the Taste Rectify the Judgment, and Mould the Heart to Virtue. $4^{\mathrm{a}}$ ed. Printed for John Wallis, \& Lee \& Hurst, London, 1798.

-Vorlesungen über Rhetorik und Schöne Wissenchaften. K. G. Schreiter, Liegnitz y Leipzig, 4 vols., 1785-9.

- Leçons de rhétorique et de belles lettres. Trad. de Cantwell, Pougin, París 1797, 4 vols.

- Lecciones sobre la retórica y las bellas letras. Trad. de J. L. Munarriz, Oficina de D. Antonio Cruzado, Madrid 1798-1801.

-Lezioni di retorica e belle lettere. Trad. de F. Soave, Parma 1801-2, 3 vols.

BLAND, Charles, The Art of Rethoric. London, 1708.

BOLINGBROKE, Henry St. John Viscount, The Philosophical Works of the Late Right Honorable Henry St. John, Lord Viscount Bolingbroke. Printed for D. Mallet, London, 1754, 5 vols.

BOSCAWEN, William, The Progress of Satire: an Essay in Verse. Printed for J. Bell, London, 1798.

Idem. 1799.

BOWLE, John, Reflections on Originality in Authors. 1766.

BRAMSTON, James, The Man of Taste, Occasion'd by an Epistle of Mr. Pope on that Subject. Printed by J. Wright for L. Gilliver, London, 1733.

BROMLEY, Robert Antony, A Philosophical and Critical History of the Fine Arts. Printed for the Author, London, 1793. Reimpresión en Garland Pu. Co., New York, 1971, 2 vols.

BROOKE, Henry, Universal Beauty. A Poem. Printed by J. Wilcox, London, 1735. Idem. Reprinted by George Faulkner, Dublin, 1736.

BROUGHTON, John, Psychologia; or an Account of the Nature of the Rational Soul. Printed by W. B. for T. Bemmet \& A. Bosvile, London, 1703.

BROWN, John, An Essay on Satire Occasion'd by the Death of Mr. Pope. Printed for R. Dodsley, London, 1745.

Idem. $2^{\text {a }}$ ed. Enlarged. 1749

-Essays on the Characteristics [of Shaftesbury]. Printed for C. Davis, London, 1751. Reimpresión en G. Olms, Hildesheim 1969.

Idem. $2^{a}$ ed. 1751 y 1752.

Idem. Printed by George Faulkner, Dublin, 1752.

Idem. $5^{\text {a }}$ ed. London, 1764. 
-A Dissertation on the Rise, Union and Power, the Progressions, Separations and Corruptions of Poetry and Music. Printed for L. Davies \& C. Reymers, London, 1763. Reimpresión en Garland Pu. Co., New York, 1971, 248 págs.

Idem. Printed by G. Faulkner, Dublin, 1763.

Idem. Printed by J. White \& T. Saint for L. Davies en Newcastle y C. Reymers en London, 1764.

-An Estimate of the Manners and Principles of the Times. Printed for L. Davies \& C. Reymers, London, 1757 ( 6 ediciones en ese año), 1758, etc.

Idem. Printed for G. Faulkner, J. Hoey \& J. Exshaw, Dublin, 1737.

Idem. Printed by Green \& Russell, Boston, 1758.

-Remarks on Some Observations on Dr Brown Dissertation on Poetry and Music. Printed for L. Davies \& C. Reymers, London, 1764.

- History of the Rise and Progress of Poetry Through its Several Pieces. Newcastle 1764. BROWN, John (not «estimate Brown»), Letters upon the Poetry and Music of the Italian Opera. Printed for Bell \& Bradfute en Edinburgh, y C. Elliot \& T. Kay en London, 1789. Idem. $2^{2}$ ed. London, 1791.

BROWNE, Isaac Hawkins, On Design and Beauty. An Epistle. Printed for J. Roberts, London, 1734.

BROWNE, Richard, Medicina Musika: or, a Mechanical Essay on the Effects of Singing, Music and Dancing on Human Bodies. Printed for J. Cook and Sold by J. \& J. Knapton, Uppingham 1729.

BURGH, James, The Dignity of Human Nature. Printed by W. B., London, 1754

Idem. A new ed. Printed for J. Johnson \& J. Payne, \& T. Cadell, London, 1767.

Idem. A new ed. in 4 books. Printed for Ch. Dilly, London, 1795.

-The Art of Speaking. Dublin, 1763.

BURKE, Edmund 6 , Philosophical Enquiry into the Origin of our Ideas of the Sublime and Beauty. Printed for R. \& J. Dodsley, London, 1757.

Idem. $2^{2}$ ed. $1759,1761,1764$.

Idem. Printed by and for S. Cotter, Dublin, 1766, 1767, 1770, 1773, 1776, 1782, 1787. Idem. A new edition. Printed by J. J. Tourneisen, Basilea 1792.

Idem. A new ed. London, 1793.

Idem. Printed at the University of Oxford, Cambridge, Edinburgh, Glasgow, St. Andrews, Aberdeen y Dublin, 1796.

Idem. A new ed. Printed for Vernor \& Hood, F. C. Rivington, T. N. Longman, Cadell \& Davies, J. Cuthel y otros, London, 1798.

-Investigación sobre el origen de nuestras ideas acerca de lo sublime y de lo bello.Trad. de J. de la Dehesa, Oficina de la Real Universidad, Alcalá 1897.

-A Philosophical Enquiry into the Origin of our Ideas of the Sublime and Beauty. Edición e introducción de A. Phillips, Oxford University Press, Oxford 1990.

6 P. J.Stanlis y C. I. Gandy, E. Burke: A Bibliography of Secondary Studies to 1982. Nueva York: Garland Pu. Co., 1982; W. B. Todd, A Bibliography of E. Burke. Surrey: St Paul's Bibliographies, 1982. 
-Investigación sobre el origen de nuestras ideas acerca de lo sublime y de lo bello. Estudio introductorio y traducción de M. Gras Balaguer, Tecnos, Madrid 1987.

BURNEY, Charles, General History of Music from the Earliest Ages to the Present Period. Printed for the Author and Sold by T. Becquet, J. Robson \& G. Robinson, London, 1776-89.

-Present State of Music in France and Italy. London, 1771.

Idem. $2^{a}$ ed. corregida. 1773.

BUSBY, Thomas, A Complete Dictionary of Music. Printed for R. Phillips and Sold by T. Hurst, London, 1786.

BYSSHE, Edward, The Art of English Poetry. Printed for R. Knapclock, E. Castle, \& B. Tooke, London, 1702.

Idem. $2^{a}$ ed. Corrected and Improved. Printed for S. Buckley and Sold by D. Midwinter, London, 1705.

Idem. 1708, 1710, 1714, 1718, etc.

-The British Pamassus: or, a Compleat Common-Place-Book of English Poetry. Printed by J. Nut and Sold by J. Pemberton \& J. Morphew, London, 1714, 2 vols.

CAMPBELL, Alexander, An Introduction to the History of Poetry in Scotland. Sold by A. Foulis, Edinburgh, 1798.

CAMPBELL, Archibald, Arete-logia or, an Enquiry into the Original of Moral Virtue, Wherein it is Shwen that Virtue Is Founded in the Nature of the Things, with Some Reflections on a Later book, Intitled, an Enquiry into the Original of our Ideas of Beauty and Virtue. Printed J. Cluer \& A. Campbell for B. Creake, Westminster 1728.

Idem. Printed for G. Hamilton, Edinburgh, 1733.

CAMPBELL, George, Philosophy of Rhetoric. Printed for W. Strahan en London, \& T. Cadell \& W. Creech en Edinburgh, 1776, 2 vols. Reimpresión en Scholars' Facsimiles and Reprints, Delmar New York 1992, 396 págs.

-Die Philosophie der Rhetorik. Berlín 1791.

CARTER, John, The Builder's Magazine: or Monthly Companions for Architects etc. Printed for the Author and Sold by F. Newbery, London, 1774.

-The Builders Magazine: or a Dictionnary for Architects, etc. Printed for F. Newbery, London, 1779.

Idem. 1788.

-Specimens of the Ancient Sculpture and Painting, Now Remaining in the Kingdom. Published by the Author, London, 1780-7, 2 vols.

-Views of Ancient Buildings in England. Published by the Author, 1786-93, 6 vols.

- The Ancient Architecture of England. Printed by W. Bulmer, London, 1795.

CHAMBERS, Sir Williams, A Treatise on Civil Architecture. Printed by J. Haberkorn, London, 1759.

Idem. 1768

Idem. $3^{a}$ ed. Considerably Enlarged. Printed by J. Smeeton, London, 1791.

-Plans, Elevations, Sections and Perspectives of the Gardens etc. Printed by J. Haberkorn, London, 1763.

-Disssertation on Oriental Gardening. Printed by W. Griffin, London, 1772. 
Idem. 1773.

CLARKE, John, The Foundations of Morality. Printed by T. Gent and Sold by A. Bettesworth, London, 1726.

CLARKE, Jonas, The Use and Excellency of Vocal Music, in Public Worship. Printed for N. Bowes, Boston Mass. 1770.

COBB, S., Discourses on Criticism and of Poetry from «Poems on Several Occasions». 1707. Reimpreso por The Augustan Society 1946.

COCKING, William, The Art of Delivering Written Language: or an Essay on Reading. Printed by $\mathrm{H}$. Hughs for J. Dodsley, London, 1775.

COMBERBACH, Roger, A Dispute Consisting of a Preface in Favour of Blank Verse. Printed for T. \& T. Longman, London, 1755.

-The Contest; in Which Is Exhibeted a Preface in Favour of Blank Verse. Printed for T. \& T. Longman, London, 1755.

CONSTABLE, John, Reflections upon Accuracy of Style. Printed for H. Lintot, London, 1731. Reimpresión en Garland Pu. Co., New York, 1970, 246 págs.

Idem. Printed for J. Osborn, London, 1734, 1738.

COOKE, Thomas, Considerations on the Stage, and on the Advantages Which Arise to a Nation from the Encouragements of Arts. London, 1731.

- Some Observations on Taste, and on the Present State of Poetry in England. Prefixed to An Ode on Beauty. Printed for M. Cooper \& R. Dodsley, London, 1749.

Idem. $2^{a}$ ed. Printed for R. \& J. Dodsley \& M. Cooper, London, 1756.

-An Ode on Poetry, Painting and Sculpture. Printed for R. \& J. Dodsley, London, 1754.

COOKE, Williams, The Elements of Dramatic Criticism. Printed for G. Kerasly \& G. Robinson, London, 1775.

COOPER, John Gilbert, The Power of Harmony. A Poem in Two Books. Printed for R. Dodsley, London, 1745.

-Letters Concerning Taste. Printed for R. \& J. Dodsley, London, 1755.

Idem. $2^{a}$. ed. 1755, 1757. Reimpresión en Garland Pu. Co., New York, 1970, 20 págs.

COWARD, William, Licentia Poetica Discuss'd; or, the True Test of Poetry. Printed for W. Carter, London, 1709.

COWDRY, Richard, A Description of the Pictures, Statues etc. Printed for the Author and Sold by J. Robinson, London, 1751.

COZENS, Alexander, Principles of Beauty Relative to the Human Head. Printed by J. Dixwell, London, 1778.

CRAIG, Williams Marshall.., An Essay on the Study of Nature in Drawings Landscape. Printed by W. Bulmer and Co., London, 1793.

CRUNDEN, John, The Carpenter's Companion for Chinese Railing and Gates. Printed for $\mathrm{H}$. Webley, London, 1765.

Idem. 1770.

-Convenient and Ornamental Architecture Consisting of Original Designs. Printed for $\mathrm{H}$. Webley, London, 1767.

Idem. 1770, 1785, 1788, 1791, 1797. 
CUMBERLAND, George, A Poem on the Landscapes of Great Britain. Printed by J. Wilson, London, 1793.

-Thoughts on Outline, Sculpture etc. Printed by W. Wilson and Sold by M. Robinson \& T. G. Egerton, London, 1796.

CUMBERLAND, Richard, Philosophical Enquiry into the Laws of Nature. Trans. by J. Towers from the Latin The legibus naturae disquisitio philosophica [J. Carson, Dublin, 1720] Printed by S. Powell, Dublin, 1750.

-A Treatise of the Laws of Nature. Reimpresión en Garland Pu. Co., New York, 1978, 740 págs.

DENNIS, John, The Advancement and Reformation of Modern Poetry. A Critical Discourse in Two Parts. Printed for R. Parker, London, 1701. Reimpresión en Garland Pu. Co., New York, 1971, 216 págs.

Idem. $2^{a}$ ed. Printed for the Author, London, 1725.

-Essays on the Operas After the Italian Manner. Printed by J. Nutt, London, 1706.

-Reflections Critical and Satirical Upon an Essay upon Criticism. B. Lintott, London, 1711. Reimpresión en The Scholar Press, Menston 1971.

-An Essay on the Genius and Writings of Shakespeare with Some Letters of Criticism to the Spectator. Printed by B. Lintott, London, 1712.

-The Grounds of Criticism in Poetry, Contained in Some New Discoveries Never Made Before. Printed for G. Straham \& B. Lintott, London, 1704. Reimpresión en Garland Pu. Co., New York, 1971, 127 págs. También en Thoemmes Press, London, 1994.

-The Impartial Critik: or Some Observations on a Late Book Entituled a Short View of Tragedy, Written by Mr. Rymer. Printed for R. Taylor, London, 1693. Reimpresión en Garland Pu. Co., New York, 1973.

-The Select Works of Mr. John Dennis. 2 vols. Printed by J. Derby, London, 1718, 2 vols. Idem. 1721.

-Vice and Luxury Publick Mischiefs: or, Remarks on a Book Intituled, The Fable of the Bees. Printed for W. Wears, London, 1724.

-The Critical Works of John Dennis. The John Hopkins University Press, Baltimore 1939.

DARWIN, Erasmus, The Botanic Garden. Printed for J. Johnson, London, 1789-3, 2 vols.

D'ISRAELI, Isaac, A Defence of Poetry. 1790.

- Curiousities of Literature. Printed for J. Murray, London, 1791. Reimpresión en Garland Pu. Co., New York, 1971, 2 vols.

Idem. $4^{\mathrm{a}}$ ed. 1794.1798.

-An Essay on the Manners and Genius of the Literature Character. Printed for T. Cadell \& W. Davis, London, 1795. Reimpresión en Garland Pu. Co., New York, 1970,226 págs.

-Calamities of Authors, Including Some Inquiries Respecting Their Moral and Literary Characters. Printed for J. Eastburn, New York, 1812, 2 vols. Reimpreso en Johnson Reprint Corp., New York, 1971, 2 vols. 
-A Dissertation on Anecdotes. 1793. Reimpresión en Garland Pu. Co., New York, 1972, 83 págs.

- Miscellanies, or, Literary Recreations. 1796. Reimpresión en Garland Pu. Co., New York, 1970, 432 págs.

- Quarrels of Authors; or, Some Memoirs for our Literary History, Including Specimens of Controversy to the Reign of Elizabeth. Reimpreso en Johnson Reprint Corp., New York, 1970, 3 vols.

-The Works. Ed. de B. Disraeli, G. Olms, Hildesheim 1969, 4 vols.

DONALDSON, John, The Elements of Beauty: also Reflections on the Harmony of Sensibility and Reason. Printed for Ch. Elliot en Edinburgh, y T. Cadell en London, 1780.

DOSSIE, Robert, The Handmaid to the Arts. Printed for J. Nourse, London, 1758, 2 vols.

Idem. $2^{\mathrm{a}}$ ed. 1764.

Idem. Printed for A. Millar, etc. London, y York 1796.

DRAKE, Nathan, Literary Hours, or Sketches Critical and Narrative. Printed for J. Burkitt and Sold by T. Cadell, London, 1798.

DUFF, William, An Essay on Original Genius and its Various Modes of Exertion in Philosophy and the Fine Arts, Particularly in Poetry. Printed for E. \& Ch. Dilly, London, 1767. Reimpresión en Garland Pu. Co., New York, 1970, 296 págs. También en Thoemmes Press, London, 1994.

-Critical Observations on the Writings of the Most Celebrated Writers and Original Geniuses in Poetry. Being a Sequel of the Essay on Original Genius. Printed for T. Becket \& P. A. de Honot, London, 1770. Reimpresión en Garland Pu. Co., New York, 1971, 366 págs.

DURHAM, W. H., Critical Essays of the Eighteenth Century: 1700-1725, Oxford University Press, Oxford 1915.

EASTCOTT, Richard, Sketches of the Origin, Progress and Effects of Music. With an Account of the Ancient Bards and Minstrels. Printed and Sold by S. Hazard, Bath 1793.

ELSUM, John, The Art of Painting After the Italian Manner. Printed for D. Brown, London, 1703.

Idem. 1704.

-A Description of the Celebrated Pieces of Painting. Printed for D. Brown, S. Clarck \& C. King, London, 1704.

FALCONER, William, Thoughts on Style and Taste in Gardening Among the Antients, in Twenty Essays on Literary and Philosophical Subjects. Dublin, 1791.

FELTON, Henry, A Dissertation on Reading the Classics and Forming a Just Style. Printed for J. Bowyer, London, 1713.

Idem. $2^{2}$ ed. 1715. Reimpresión en Garland Pu. Co., New York, 1972, 274 págs.

Idem. $3^{\text {a }}$ ed. $1718,1723$.

Idem. $4^{a}$ ed. Printed for B. Motte, London, 1730.

Idem. $5^{a}$ ed. Printed for R. Baldwin, London, 1753. 
FERGUSON, Adam, Essay on the History of Civil Society. Printed for A. Millar \& T. Cadell en London, y A. Kincaid \& J. Bell en Edinburgh, 1767. Reimpresión en Garland Pu. Co., New York, 1971, 430 págs.

Idem. Printed by Boulter Grierson, Dublin, 1767.

Idem. $2^{a}$ ed. London, 1768, 1768, 1773.

Idem. A new ed. Printed by J. J. Tourneisen, Basilea 1789.

Idem. $6^{a}$ ed. London, 1793.

-Versuch über die Geschichte der bürgerlichen Gesselchaft. Leipzig 1768.

-Essai sur l'histoire de la societé civile. Trad. de M. Bergier, París 1783.

-Fundamental Principles of Virtue and Morality. 2 vols. Edinburgh, 1792. Reimpresión en G. Olms, Hildesheim 1975.

FERGUSON, James, Art of Drawing in Perspective Made Easy. Printed for W. Strahan \& T. Cadell, London, 1775.

Idem. $2^{\mathrm{a}}$ ed, 1778.

FIDDES, Richard, «Imagination» en A General Treatise of Morality. Printed for S. Billingsley, London, 1724.

FOOTE, Samuel, The Roman and English Comedy Consider'd and Compar'd. Printed by A. Reilley for E. \& J. Exshaw, London, 1747.

FORBES OF PITSLIGO, Alexander, Essays Moral and Philosophical. Printed for J. Osborne \& T. Longman, London, 1734.

Idem. 1762 y 1763.

FORDYCE, David, Dialogues Concermig Education. 2 vols. Printed in the year, London, 1745-48.

Idem. 2 vols. $3^{\text {a }}$ ed. Printed by H. \& R. Joy, Belfast 1753.

Idem. 2 vols. $4^{\mathrm{a}}$ ed. Printed for Ph. \& G. Bagnell, Cork 1755.

Idem. $4^{\circ}$ ed. Printed for E. Dilly, London, 1757.

Idem. Glasgow 1768.

-Elements of Moral Philosophy. In Three Books. Printed for R. \& J. Dodsley, London, 1754.

Idem. 1758.

Idem. $4^{2}$ ed. Printed for J. Dodsley, London, 1769.

-Theodorus: A Dialogue Concerning the Art of Preaching. Printed by R. \& J. Dodsley, London, 1752, 225 págs.

Idem. Printed for G. \& A. Ewing, Dublin, 1752.

Idem. Printed for R. Dodsley, London, 1753 y 1755.

-Elements de philosophie morale. Trad. de M. de Joncourt, La Haya 1757.

-Des Herrn Fordyce. Anfangsgründe der moralischen Weltweisheit. Zurich 1756.

FORTESCUE, James, A View of Life in its Several Passions. Printed for M. Cooper, London, 1749.

FOURNIER, Daniel, A Treatise of the Theory and Practice of Perspective. Printed by the Author and Sold by Mr. Nourse \& Mr. Lacey, London, 1761.

Idem. $2^{\mathrm{a}}$ ed. 1764. 
FRANCKLIN, Thomas, A Dissertation on Ancient Tragedy. ¿London,? 1760.

Idem. London, 1768.

FRENEAU, Phillip, The Power of Fancy. 1770.

-The Miscellaneous Works of Mr. Phillip Freneau Containing His Essays and Additional Poems. Printed by F. Bailey, Filadelfia 1788.

GALLY, Henry, The Moral Character of Teophrastus with an Essay on Characterwriting. Printed for J. Hooke, London, 1725.

GAY, John, Dissertation on the Fundamental Principles of Virtue or Morality. 1731.

GEDDES, James, Essay on the Composition and Manner of Writing of the Ancients, Particularly Plato. Printed and Sold by R. Foulis, Glasgow 1748.

GENTLEMAN, Francis, The Orator: or, English Assistant. Being an Essay on Reading and Declamation. Edinburgh, 1771.

-Introduction to Shakespeare's Plays. Printed for J. Bell \& C. Etherington, London, y York 1773.

Idem. 1774.

- Dramatic Censor or Critical Companion, London, 1770.

GERARD, Alexander, An Essay on Taste. With Three Dissertations on the Same Subject, by Voltaire, D'Alembert, and Montesquieu. Printed for A. Millar \& A. Kinkaid en London, y J. Bell en Edinburgh, 1759. Reimpresión en The Scholar Press, Menston 1971.

Idem. $2^{\mathrm{a}}$ ed. Printed for A. Millar en London, y A. Kinkaid \& J. Bell en Edinburgh, 1764. Reimpresión en Garland Pu. Co., New York, 1970, 298 págs.

-An Essay on Genius. Printed for W. Strahan \& T. Cadell en London, y W. Creech en Edinburgh, 1774.

-An Essay on Taste. To Which is Now Added Part Fourth, of the Standard of Taste: with Observations Concerning the Imitative Nature of Poetry. $3^{a}$ ed. Edinburgh, 1780.

-Essai sur le goût. Trad. de M. A. Eidons, París y Dijon 1766.

-Versuch über den Geschmack. Breslau y Leipzig 1766.

GIBBON, Edwards, Essai sur l'étude de la litterature. Chez T. Beckett \& P. A. De Hont, London, 1761.

Idem. 1762.

Idem. Traducción al inglés. Printed for T. Becket \& P. A. De Hont, London, 1764, 1788.

Idem. Chez G. Halhead, Dublin, 1777.

-Critical Observations on the Sixth Book of the Aeneid. Printed for P. Elsmley, London, 1770.

Idem. 1794.

GIBBONS, Thomas, Rhetoric: or a View of Its Principal Trapes and Figures, in Their Origin and Powers. Printed by J. \& W. Oliver and Sold by J. Buckland \& J. Payne, London, 1767.

GIBBS, James, Rules for Drawing the Several Parts of Architecture. Printed by W. Bowyer, London, 1732. 
Idem. $2^{\mathrm{a}}$ ed. Printed for A. Bettesworth y otros, London, 1738.

-A Book of Architecture. 1728.

$2^{a}$ ed. Printed for W. Innys y otros, London, 1739.

GILDON, Charles, The Complete Art Poetry. Printed for Ch. Rivington, London, 1718. Reimpresión en Garland Pu. Co., New York, 1970, 2 vols.

- The Laws of Poetry as Lai'd Down by the Duke of Buckinghamshire. London, 1721. Reimpresión en Garland Pu. Co., New York, 1970, 359 págs.

GILPIN, W., An Essay upon Prints, Containing Remarks upon the Principles of Picturesque Beauty. Printed for J. Robson, London, 1768.

Idem. $3^{\text {a }}$ ed. Printed by G. Scott for R. Blamire, London, 1781, 1792.

-Observations on the River Wye, and Several Parts of South Wales etc., Relative Chiefly to Picturesque Beauty. Printed for R. Blamire and Sold by L. Law \& R. Faulder, London, 1782.

Idem. 1789. 1792.

-Observations Relative chiefly to Picturesque Beauty etc, Printed for R. Blamire, London, 1786, 2 vols.

Idem. 1788, 1792.

-Three Essays: on Picturesque Beauty, on Picturesque Travel and on Sketching Landscape. Printed for R. Blamire, London, 1792.

Idem. 1794.

-Voyages en différent parties de l'Angleterre contenant des observations relatives aux beautées pictoresques. Chez D. de Maisonneuve \& Blamire, París y London, 1789.

GOLDSMITH, Oliver, An Enquiry into the Present State of Polite Learning in Europe. Printed for R. \& J. Dodsley, London, 1759.

- Essays. Printed for R. Griffin, London, 1765.

GREEN, John, Beauty, a Poem. 1756.

GREENE, Edward Burnaby, Critical Essays. Printed by T. Spilsbury for J. Ridley, London, 1770.

-Poetical Essays. Printed for J. Ridley, London, 1771.

Idem. 1772.

GREGORY, John, A Comparative View of State of the Faculties of Man. With Those of the Animal World. Printed for J. Dodsley, London, 1765.

Idem. $2^{a}$ ed. $1766,1772,1774$ y 1777.

Idem. Printed for A. Strahan \& T. Cadel en London, y W. Creech en Edinburgh, 1788. Idem. A new edition Printed for T. Cadell \& W. Davies, London, 1798.

GWYNN, John, An Essay on Design: Including Proposals for Erecting a Public Academy. Printed and Sold by I. Brindley, London, 1749.

Idem. Printed for G. Faulkner, Dublin, 1749.

-London, and Westminster Improved, Illustrated by Plans. To Which is Prefixed, a Discourse on Publik Magnificence. Printed for the Author and Sold by Mr. Dodsley, London, 1766. 
HALL, Sir James, Essay on the Origin and Principles of Gothic Architecture. From the Transactions of the Royal Society of Edinburgh. Leído el 6 de Abril de 1797. Edinburgh, 1797.

HALL, Samuel, An Attempt to Show that a Taste for the Beauties of Nature and the Fine Art has no Influence Favorable to Morals. 1785.

HARINGTON, Edward, A Schizzo on the Genius of Man. Printed by R. Bath, London, 1793.

HARRIS, James, Three Treatises: The First Concerning Art, the Second Concerning Music, Painting and Poetry, the Third Concerning Happiness. Printed by $\mathrm{H}$. Woodfall for J. Nourse \& P. Vaillant, London, 1744. Reimpresión en Garland Pu. Co., New York, 1970, 377 págs.

Idem. 1765,1772 y 1783.

Idem. $5^{\mathrm{a}}$ ed. Printed for F. Wingrave, London, 1792.

-Upon the Rise and Progress of Criticism. ¿London,? 1752. Reimpresión en Garland Pu. Co., New York, 1971, 48 págs.

-The Works of James Harris. A new edition. Printed by L. Hansard for F. Wingrave, London, 1799-1806, 5 vols.

HARTE, Walter, An Essay on Reason. Printed by J. Wright for Lawton Gilliver, London, 1735.

Idem. $2^{\mathrm{a}}$ ed. $1735,1736$.

-An Essay on Satire, Particularly on the Dunciad. Introducción de T. B. Gilmore, AMS Press, New York, 1992.

HARTLEY, David, Observations on Man. His Frame, his Duty, and his Expectations. Printed for the Author, London, 1749.

$2^{\circ}$ ed. Printed for J. Johnson, London, 1791. Reimpresión en G. Olms, Hildesheim 1967,2 vols.

-[Observations on Man $]$ Hartley's Theory of the Human Mind. Printed for J. Johnson, London, 1775.

HAWKINS, Sir John, An Account of the Institution and Progress of the Academy of Ancient Music. London, 1770.

-A General History of the Science and Practice of Music. Printed for T. Payne, London, 1776,5 vols.

HAWKINS, Thomas, The Origins of the English Drama Illustrated in Its Various Species. Clarendon Press \& S. Leacroft, Oxford y London, 1773.

HAYES, W., Remarks on Mr. Avison's Essay on Musical Expression. London, 1753.

HAYLEY, William, A Poetic Epistle to an Eminent Painter. Printed for T. Payne, London, 1778.

-An Elegy on the Ancient Greek Model. Printed by F. Hodson in Cambridge and Sold by T. Payne in London, 1779.

- An Essay on Painting. $3^{\circ}$ ed. Printed for J. Dodsley, London, 1781.

-An Essay on Epic Poetry. J. Dodsley, London, 1782. Reimpresión en Scholars' Facsimiles and Reprints, Gainesville, Fla. 1968, 298 págs.

-A Poetical Epistle to an Eminent Painter, an Elegy on the Ancient Greek Model, Epistle to Admiral Keppel, Epistle to a Friend on the Death of John Thornton, an 
Essay on History. Garland Pu. Co., New York, 1978, 307 págs. Reimpresión de 5 obras publicadas entre 1778 y 1780.

-An Essay on Sculpture. Introducción de D. H. Reiman, Garland Pu. Co., New York, $1978,358 \mathrm{p}$.

HEELY, Joseph, Letters on the Beauties of Hagley, Envil and the Leasowes With Critical Remarks: and Observations on the Modern Taste in Gardening. Printed for the Author and Sold by R. Badwin, London, y Birmingham 1777.

HENRY, Thomas, Twenty Essays on the Advantages of Literature and Philosophy in General, and Specially on the Consistency of Literary and Philosophical With Commercial Pursuits. Dublin, 1791.

HEPPESLEY, John, A Dissertation on Commedy... by a Student of Oxford. London, 1750.

HIGHMORE, Joseph, A Critical Examination of Those Two Paintings etc., Printed for J. Nourse, London, 1754.

-Whether Artists Only Are Proper Judges of Works of Arts en Essays Morals, Religious and Miscellaneous. Printed for B. White \& J. Walter, London, 1766, 2 vols.

HILL, Aaron, Essay on the Art of Acting. Printed for J. Dixwell, London, 1779.

-The Progress of Wit. A Caveat. Printed for J. Wilford, London, 1730.

HILL, John, The Actor: a Treatise on the Art of Playing. Printed for R. Griffiths, London, 1750.

Idem. 1755.

HOGARTH, William, The Analysis of Beauty, Written With a View of Fixing the Fluctuating Ideas of Taste. Printed by J. Reeves for the Author, London, 1753. Reimpresión en Garland Pub., New York, 1973, 153 págs.

-Works. 3 vols., London, 1874.

-The Analysis of Beauty. Clarendon Press, Oxford 1955.

- Análisis de la belleza, edición M. Cereceda, traducción de M. Cereceda y R. M. Criado Talavera, Visor, Madrid, 1997.

HOLDEN, John, An Essay Toward a Rational System of Music. Printed by R. Urie, Glasgow 1770.

HOLMES, John, The Art of Rhetoric Made Easy, or the Elements of Oratory. Printed by A. Parker, London, y Dublin, 1739.

Idem. $2^{a}$ ed. 1755.

Idem. Printed by J. Exshaw. Dublin, 1758.

Idem. Printed by L. Hawes. London, 1776.

HUME, David7, A Treatise of Human Nature. Printed by J. Noon, London, 1739-40.

- Essays Moral and Political. Printed by R. Fleming \& A. Alison, Edinburgh, 1742. Idem. Printed for A. Kinkaid, R. Fleming \& A. Alison, Edinburgh, 1742.

Idem. $2^{\mathrm{a}}$. ed. Printed for A. Kinkaid, Edinburgh, 1742.

7 R. Hall, A Hume Bibliography. York: University of York, 1971; Id., Fifty Years of Hume Scholarship. Edimburgo: Edinburgh University Press, 1978. 
Idem. $3^{\text {a }}$. ed. Printed for A. Millar en London, \& A. Kinkaid en Edinburgh, 1748.

-Philosophical Essays Concerning Human Understanding. Printed for A. Millar, London, 1748.

Idem. $2^{\text {a }}$. ed. Printed for A. Millar, London, 1750.

Idem. Printed for M. Cooper, London, 1751.

-Three Essays, Moral and Political. 2 vols. Printed for A. Millar en London, y A. Kinkaid en Edinburgh, 1748.

—Four Dissertations. Printed for A. Millar, London, 1757.

-Essays and Treatises on Several Subjects. A new edition. Printed for A. Millar en London, y A. Kinkaid \& A. Donaldson en Edinburgh, 1758.

Idem. 4 vols. A new ed. 1760, 1764, 1767 y 1768.

Idem. 4 vols. A new ed. Printed for T. Cadell en London, y A. Kinkaid \& A. Donaldson en Edinburgh, 1770.

Idem. 2 vols. Printed for T. Cadell en London, y A. Donaldson \& W. Creech en Edinburgh, 1777.

Idem. 2 vols. A new ed. Printed by J. Williams, Dublin, 1779.

Idem. To Which is Added Dialogues Concerning Natural Religion. A new edition.

Printed for T. Cadell en London, y Bell, Bradfute \& T. Duncan en Edinburgh, 1793.

-Discours politiques de Mr. D. Hume. Schreuder \& Mortier, Amsterdam 1754.

-Vermischte Schriften. Hamburgo y Leipzig, 4 vols. 1754-6.

- Saggi morali e politici. Amsterdam 1764.

-Oeuvres philosophiques de Mr. D. Hume. Amsterdam 1758-60, 5 vols.

-Pensées philosophiques, morales, critiques, littéraires et politiques. Trad. de J. A. de Boulmiers, London, ¿París? 1767.

-Die Vier Philosophen. Glogau 1768.

- Le temple du bonheur. Ed. de J. F. Dreux du Radier, Bouillon 1768.

-Le génie de M. Hume. London, ¿París? 1770.

-Das Genie des Hrn. Hume. Leipzig 1774.

- Über die menschliche Natur. L. H. Jacobi, Halle 1790-2.

-Untersuchungen über den menschlichen Verstand. Jena 1793.

-A Treatise of Human Nature, Ed. de Selby-Bigge revisada por P. H. Niddicht, Clarendon Press, Oxford 1985.

-Enquiries Concerning Human Understanding and Concerning the Principles of Morals. Ed. de Selby-Bigge revisada por P. H. Niddicht, Oxford University Press, Oxford 1975.

-Essays. Ed. de T. H. Green, Longman, London, 1907.

-Tratado de la naturaleza humana. Trad. de F. Duque, Tecnos, Madrid 1988.

-Investigación sobre el conocimiento humano. Trad. de J. de Salas, Alianza, Madrid 1980.

-Investigación sobre los principios de la moral. Trad de G. López Sastre, Austral, Madrid 1991.

-Disertación sobre las pasiones y otros ensayos morales. Ed. de J. L. Tasset, Anthropos, Barcelona 1990. 
- La norma del gusto y otros ensayos. Trad. de M. T. Beguiristain, Península, Barcelona 1989.

HURD, Richard, Q. Horatii Flacci Ars Poetica, With an English Commentary and Notes. 1749.

-Q. Horatii Facci Epistola ad Augustum, With an English Commentary and Notes, to Which Is Added a Discourse Concerning Poetical Imitation. 1751.

-A Letter to Mr. Mason, on the Marks of Imitation. Printed for W. Thurlbourn \& J. Wooddyer, Cambridge 1757.

-Letters on Chivalry and Romance. Printed for A. Millar en London, $\mathrm{y}$ W. Thurlbourn \& J. Woodyer en Cambridge, 1762. Reimpresión en Garland Pub., New York, 1971, 120 págs.

Idem. $2^{a}$ ed. 1762.

Idem. Printed for R. Watts, Dublin, 1762.

HURDIS, James, Lecture Shewing the Several Sources of That Pleasure Which the Human Mind Receives From Poetry. Printed by the Author and Sold by J. Johnson, Sussex, Oxford y London, 1797.

HUTCHESON, Francis 8 , An Inquiry into the Originals of Our Ideas of Beauty and Virtue. Printed by J. Darby for Will en London, y J. Smith en Dublin, 1725.

Idem. $2^{2}$ ed. Printed for J. Darby, A. Bettesworth, F. Fayram, J. Pemberton, C. Rivington, J. Hooke, F. Clay, J. Batley \& E. Simon, London, 1726.

Idem. $3^{\mathrm{a}}$ ed. 1729.

Idem. $4^{a}$ ed. 1738.

Idem. $5^{\mathrm{a}}$ ed. Printed for R. Ware y otros, London, 1753.

Idem. Printed from the fourth edition by R. \& A. Foulis, Glasgow 1772.

-An Essay in the Nature and Conduct of the Passions and Affections. Printed by $\mathrm{J}$. Darby \& T. Browne, for J. Smith en London, y W. Bruce en Dublin, 1728.

Idem. Printed for J. \& J. Knapton, J. Crownfiel, J. Darby, Th. Osborne \& L. Gilliver, London, 1730.

Idem. $3^{\text {a }}$ ed. Printed for A. Ward, J. \& P. Knapton, T. Longman, S. Birt, C. Hitch y otros, London, 1742.

Idem. $4^{\text {a }}$ ed. Printed for W. Innys \& J. Richardson, S. Birt, C. Hitch \& L. Hawes y otros, London, 1756.

-A System of Moral Philosophy. Printed and Sold by R. \& A. Foulis, London, Glasgow, 1755.

-Recherche sur l'origine des idées que nous avons de la beauté et de la vertue. Amsterdam 1749, 2 vols.

-Sittenlehre der Vermunft. Leipzig 1756, 2 vols.

-Untersuchungen unster Begriffe von Schönheit und Tugend. Trad. de J. H. Merk, Frankfurt y Leipzig 1762.

8 Una bibliografía actualizada de Hutcheson puede encontrarse en la traducción castellana realizada por J. V. Arregui de F. Hutcheson, Investigación sobre el origen de nuestra idea de belleza. Madrid: Tecnos, 1992. 
-System de philosophie morale. Lyon 1770, 2 vols.

-An Inquiry Concerning Beauty, Order, Harmony, Design. Edición, introducción y notas de P. Kivy, M. Nijhoff, La Haya 1973, 123 págs.

-[Reflections on Our Common Systems of Morality] On Human Nature. Ed. de T. Mautner, Cambridge University Press, Cambridge 1993.

-Illustrations on the Moral Sense. Ed. de B. Peach, Belknap Press of Harvard University Press, Cambridge (Mass.) 1971.

-Collected Works. G. Olms, Hildesheim 1969-70.

-An Inquiry into the Originals of Our Ideas of Beauty and Virtue. Reimpresión de la edición de 1726, Garland Pu. Co., New York, 1971.

-An Inquiry into the Originals of our Ideas of Beauty and Virtue. Reimpresión de la edición de 1738, Gregg, Farnborough 1969.

-Essay and Illustrations. Reimpresión de la edición de 1728, Garland Pu. Co., New York, 1971.

-Essay and Illustrations. Reimpresión de la edición de 1728, Scholar Press, Menston, Yorkshire 1972.

-Eine Untersuchungen über den Ursprung unserer Ideen von Schönheit und Tugend. Trad. de W. Leidhold, Meiner, Hamburgo 1986.

-Recherche sur l'origine de nos idées de la beauté et de la vertue. Trad. de A. D. Balmès, J. Vrin, París 1991.

-Una investigación sobre el origen de nuestra idea de belleza. Estudio preliminar, traducción y notas de J. V. Arregui, Tecnos, Madrid 1992.

JACKSON, William, Thirty Letters on Various Subjects. 2 vols. Printed for T. Cadell \& T. Evans en London, y B. Thorn and Son en Exeter, 1783.

Idem. $2^{2}$ ed. 1784. Reimpresión en Garland Pub., New York, 1970, 2 vols.

Idem. $3^{\text {a }}$ ed. 1795.

- Observations on the Present State of Music in London. London, 1791.

-The Four Ages, Together With Essays on Several Subjects. London, 1798.

JAMESON, Williams, An Essay on Virtue and Harmony. Printed by T. \& W. Ruddimans for G. Hamilton \& J. Balfour, Edinburgh, 1749, 321 págs.

JARDINE, G., Synopsis of Lectures on Logic and Belles Lettres Read in the University of Glasgow. Glasgow 1797.

JENYNS, Soame, The Art of Dancing, a Poem in Three Cantos. Printed by W. P. and Sold by J. Robinson, London, 1729.

Idem. Printed for M. Cooper. London, 1744.

-The Modern Fine Gentleman. Printed for M. Cooper, London, 1746.

-The Modern Fine Lady. Printed for M. Cooper, London, 1751.

JOHNSON, Samuel, A Dictionary of the English Language. 2 vols. Printed by W. Strahan for J. \& P. Knapton, T. \& T. Longman, C. Hitch \& L. Hawes, A. Millar, \& R. \& J. Dodsley, 1755.

- Veintidós ediciones repartidas entre London, y Dublin. Una en Edinburgh. 
JONES, William, Poems Consisting Chiefly of Translations from the Asiatick Languages. To Which Are Added Two Essays: 1. On the Poetry of the Eastern Nations. 2. On the Arts, commonly called Imitative, Oxford, 1772.

JONES, William of Nayland, A Treatise on the Art of Music. Colchester 1784.

KAMES, Henry Home Lord, Essays on the Principles of Morality and Natural Religion. Printed by R. Fleming, for A. Kinkaid \& A. Donaldson, Edinburgh, 1751.

Idem. $2^{a}$ ed. Printed for C. Hitch \& L. Hawes, R. \& J. Dodsley, J. Rivington \& J. Fletcher, \& J. Richardson, London, 1758. Reimpresión en G. Olms, Hildesheim 1976, 309 págs.

Idem. $3^{a}$ ed. Edinburgh, 1789.

-Elements of Criticism. 3 vols. Printed for A. Millar en London, y A. Kinkaid \& J. Bell en Edinburgh, 1762. Reimpresión en G. Olms, Hildesheim 1970, 3 vols.

Idem. 3 vols. $2^{a}$ ed. 1763.

Idem. $4^{2}$ ed. Printed for A. Millar \& T. Cadell en London, y A. Kinkaid, \& J. \& J. Bell en Edinburgh, 1769.

Idem. $6^{a}$ ed. Printed for J. Bell \& W. Creech en Edinburgh, y T. Cadell \& G. Robinson en London, 1785, 1788.

Idem. $7^{3}$ ed.

First American Edition from the Seventh of London, The Press of S. Etheridge, for J. White, Th. \& Andrews, W. Spotwoods, D. West y otros, Boston 1796.

-Grundsätze der Critik. Trad. de J. N. Meinhard, Leipzig, 1763-6, 3 vols.

-Versuch über die ersten Grunde der Sittlichkeit. C. G. Rautenberg, Brunswick 1768, 2 vols.

KEEBLE, John, The Theory of Harmonics: or, an Illustration of the Grecian Harmonica. Printed for the Author and Sold by J. Walter y otros, London, 1784.

KERSHAW, Thomas, On the Comparative Merits of the Ancients and Moderns, With Respect to the Imitative Arts, in Twenty Essays on Literary and Philosophical Subjects. Dublin, 1791.

KIRBY, Thomas, An Essay on Criticism. London, 1758.

KNIGHT, Richard Payne, The Landscape, a Didactic Poem in Three Books. Addressed to Uvedale Price. Printed by W. Bulmer and Co., London, 1794.

Idem. $2^{a}$ ed. 1795.

KNOX, Vicesimus, Essays, Moral and Literary. 2 vols. Printed for E. \& Ch. Dilly, London, 1778-9. Reimpresión en Garland Pu. Co, New York, 1972, 2 vols.

Idem. $2^{3}$ ed. $1779,1782$.

Idem. A new ed. Printed by R. Marchblank, Dublin, 1783.

Idem. $4^{\mathrm{a}}$. ed. London, 1784, 1784, 1785, 1787, 1791, 1793.

Idem. 2 vols. $12^{\mathrm{a}}$ ed. Printed by T. Allen, New York, 1793 .

Idem. $14^{a}$ ed. London, 1795.

KOLLMAN, Augustus F. C., An Essay on Musical Harmonny According to the Nature of That Science and the Principles of the Greatest Musical Authors. Printed by J. Dale, London, 1796. 
-An Essay on Practical Musical Composition According to the Nature of That Science and the Principles of the Greatest Musical Authors. Printed for the Author and Sold by Mr Dale, London, 1799.

LAMOTTE, Charles, An Essay upon Poetry and Painting With Relation to the Sacred and Profane History. With an Appendix Concerning Obscenity in Writing and Painting. F. Fayram, London, 1730. Reimpresión en Garland Pu. Co., New York, 1970,2 vols.

Idem. 1731.

Idem. Printed by T. Bacon, Dublin, 1742.

Idem. Printed by I. Kelly, Dublin, 1745.

$\rightarrow$ A Letter on the Nature and State of Curiosity. London, 1786.

LAMPE, John Frederick, The Art of Music. Printed for C. Corbett, London, 1740.

LANGHOERNE, John, Letters on the Eloquence of the Pulpit. London, 1765.

LANGLEY, B., New Principles of Gardening, or, the Laying Out and Planting of Pastures, Groves, Wildernesses etc. London, 1728.

LAW, William, Case of Reason, or Natural Religion, Fairly and Fully Stated. Printed for W. Innys, London, 1731.

Idem. $2^{a}$ ed. 1755.

Idem. $3^{\mathrm{a}}$ ed. Printed for G. Robinson, London, 1774.

LAWSON, John, Lectures Concerning Oratory. Dublin, 1758.

LAURENCE, John, The Clergy-Man's Recreation: Shewing the Pleasures and Profit of the Art of Gardening. London, 1714.

Idem. $3^{a}$ ed. 1715.

Idem. $4^{a}$ ed. 1716.

Idem. $5^{\text {a ed. }} 1717$.

Idem. $6^{a}$ ed. 1726.

-The Gentleman's Recreation, Printed for B. Lintott, London, 1716.

Idem. 1717.

- Gardening Improv'd containing I. The Clergyman's Recreation. II. The Gentleman's Recreation. Printed by M. Taylor, London, 1718.

Idem. Printed for G. Grierson, Dublin, 1719.

-Paradise Regain'd or, the Art of Gardening. A Poem. London, 1728.

LEE, Henry, Anti-Scepticism: or, Notes upon Each Chapter of Mr. Locke's Essay Concerning Human Understanding. Printed for R. Clavel \& C. Harper, London, 1702. Reimpresión en Garland Pu. Co, New York, 1978, 342 págs.

LELAND, Thomas, A Dissertation on the Principles of Human Eloquence. London, 1764.

LEMOINE, Henry, The Art of Speaking upon an Entire New Plan. London, 1797.

LOWTH, Robert, De Sacra Poesia Hebraeorum Praelectiones. Clarendon Press, Oxford 1753. Trad. de G. Gregory con notas del Professor Michaelis y otros publicada como Lectures on the Sacred Poetry of the Hebrews. 1787. Reimpresión en Garland Pu. Co., New York, 1971, 2 vols. 
MACAULAY, Aulay, Essays on Various Subjects of Taste and Criticism. Printed for C. Dilly, London, 1780.

MALCOLM, Alexander, A Treatise of Music Speculative, Practical and Historical. Printed for the Author, Edinburgh, 1721.

Idem. Printed for J. Osborne. London, 1730.

Idem. $2^{a}$ ed. Corrected. Printed for J. Murray \& L. White, London, y Dublin, 1779.

MALLET, David, The Excursion. Printed for J. Waltahoe, London, 1728.

MALTON, James, A Complete Treatise on Perspective. Printed for the Author and Sold by Mr. Robson y otros, London, 1775.

Idem. 1776, 1777, 1779.

-An Appendix, or Second Part, to the Compleat Treatise on Perspective. Printed for the Author and Sold by Mr. Robson y otros, London, 1783.

-An Essay on British Cottage Architecture. Published by Hookman \& Carpenter, London, 1798.

-A Picturesque and Descriptive View of the City of Dublin. Published by W. Faden, Dublin, 1799.

MANWARING, Edwards, An Historical and Critical Account of the Most Eminent Classic Authors in Poetry and in History. Printed for W. Innis \& R. Manby, London, 1737.

-Stichology: or, a Recovery of the Latin, Greek and Hebrew Numbers. Printed for the Author, London, 1737. Idem. 1738.

-Of Harmony and Numbers, in Latin and English Prose, and in English Poetry. Printed for M. Cooper, London, 1744.

MANWARING, Robert, The Cabinet and Chair-Maker's Real Friend and Companion, or the Whole System of Chair-Making. Printed for H. Webley, London, 1765.

-The Carpenter's Complete Guide to the Whole System of Gothic Railing. Printed for A. Webley, London, 1765.

- The Chair-Makers Guide. Printed for R. Sayer, London, 1766.

MARSHALL, William, Planting and Ornamental Gardening. Printed for J. Dodsley, London, 1785.

Idem. Printed for G. Nicol y otros. London, 1796.

-A Review of the Landscape, a Didactic Poem: Also of an Essay on the Picturesque Together Practical Remarks on Rural Omament. Printed for G. Nicol y otros, London, 1795.

MASON, George, An Essay on Design in Gardening. Printed for B. White, London, 1768.

Idem. $2^{a}$ ed. revised. Printed for B. \& J. White. London.

Idem. 1798, 1795.

MASON, John, An Essay on Elocution, or, Pronuntiation. Intended Chiefly For the Assistance of Those Who Instruct Others in the Art of Reading. Printed for M. Cooper, London, 1748.

Idem. $2^{\mathrm{a}}$ ed. Printed for R. Hett y otros. London, 1748, 1751.

Idem. $4^{a}$ ed. Printed for J. Buckland \& J. Waugh. London, 1757, 1761. 
-An Essay on the Power and Harmonny of the Prosaic Numbers. Printed by J. Waugh for M. Cooper, London, 1749.

Idem. $2^{a}$ ed. Printed for J. Buckland \& J. Waugh, London, 1761. MASON, William, The English Garden: a Poem. In Four Books. Printed by A. Ward,
1772-81.

Idem. 1783.

Idem. Printed by P. Byrne. Dublin, 1786.

- Essays, Historical, and Critical, on English Church Music. Printed by W. Blaanchard en York and Sold by J. Robson en London, y J. Todd en York, 1795.

MATTHEWS, John, A Sketch From the Landscape, a Didactic Poem. Printed for R. Faulder, London, 1794.

MAYNE, Charles, Two Dissertations Concerning Sense and the Imagination. Printed for J. Tonson, London, 1728.

MAXWELL, John, An Essay upon Tune, Being an Attempt to Free the Scale of Music, and the Tune of Instruments From Imperfections. Edinburgh, 1781.

MELMOTH, William, Letters of Sir Thomas Fitzosborne. Printed for R. \& J. Dodsley, London, 1749. Reimpresión en Garland Pu. Co., New York, 1971, 2 vols.

Idem. $5^{a}$ ed. 1758.

Idem. 6a ed. Printed for R. \& J. Dodsley, London, 1763, 1769.

Idem. $7^{2}$ ed. Printed for J. Bell en London, y C. Etherington en York, 1776.

Idem. 8 a ed. Printed for J. Dodsley, London, 1776 y 1784.

Idem. Printed for J. Walker, London, 1795.

Idem. Printed for J. Dodsley, London, 1795.

MELMOTH, Courtney (Samuel Jackson Pratt), The Progress of Painting. London, 1775.

-The Sublime and Beautiful in Scripture. Printed for J. Murray, London, 1777.

Idem. Printed for W. \& H. Whitestone, Dublin, 1778.

Idem. Printed for J. Murray \& G. Robinson, London, 1782, 1783.

Idem. Printed by T. O'Brien for C. Davis, New York, 1795.

MILLER, Georg, An Essay on the Origin and Nature of Our Ideas of the Sublime. A Transaction of the Royal Irish Academy, 1794.

MILLER, James, Harlequin-Horace, or the Art of Modern Poetry. Printed for L. Gilliver, London, 1731.

Idem. Printed for G. Faulkner. Dublin, 1731.

Idem. Printed for L. Gilliver. London, 1735.

MITFORD, William, An Essay upon the Harmony of Language, Intended Principally to Illustrate That off the English Language. Printed by Scott for J. Robinson, London, 1774.

MOIR, John, Gleanings, or, Fugitive Pieces. 2 vols. Printed for the Author, London, ¿1785?

MONBODDO, James Burnet, Lord, On the Origin and Progress of Language. 6 vols. Printed for A. Kinkaid \& W. Creech en Edinburgh, e Y. Cadell en London, 1773-92. Idem. vol. II. $2^{a}$ ed. Printed for J. Balfour en Edinburgh, e Y. Cadell en London, 1774-8. 
Idem. vol. III. $2^{2}$ ed. Printed for T. Cadell en London, y J. Balfour en Edinburgh, 1786. -Of the Origin and Progress of Language. With a new Preface by R. Darnell, AMS Press, New York, 1973, 6 vols. Reimpresión de la edición de 1774-1809.

MONTAGU, Elizabeth, An Essay on the Writings and Genius of Shakespeare. London, 1769. Reimpresión en A. M. Kelley, New York, 1970, 288 págs.

Idem. H. Saunders, Dublin, 1769, 1770, 1772 y 1778.

MOOR, James, On the End of Tragedy, According to Aristotle, an Essay in Two Parts. Printed for R. \& A. Foulis, Glasgow 1763.

Idem. 1794.

-Vindication of Virgil. Printed by R. \& A. Foulis, Glasgow 1766.

MORGANN, Maurice, Essay on the Dramatic Character of Sir John Falstaff. Printed for T. Davies, London, 1777. Reimpreso en AMS Press, New York, 1970, 185 págs.

MORLEY, Thomas, Introduction to Practical Music. Printed by G. Wigg, London, 1597.

Idem. Printed for W. Randall, London, 1771.

MORRIS, Corbyn, An Essay Towards Fixing the True Standards of Wit, Humour, Raillery, Satire and Ridicule. Printed for J. Roberts \& W. Bickerton, London, 1744. Reimpreso en AMS Press, New York, 1972, 75 págs.

MORRIS, Robert, An Essay in Defence of Ancient Architecture. Printed for D. Browne, London, 1728, 113 págs. Reimpreso en Research Publications, New Haven 1973.

-Lectures on Architecture. Printed for J. Brindley, London, 1734. Reimpreso en Research Publications, New Haven 1973.

Idem. Printed for R. Sayer, London, 1759.

-Rural Architecture: Consisting of Regular Designs of Plans etc, London, 1750.

-The Architectural Remembrancer: Being a Collection of New and Useful Designs of Ornamental Buildings and Decorations for Parks, Gardens, Woods etc, London, 1751. Reimpresión en Eng., Gregg, Farnborough 1971.

- Architecture Improved in a Collection of Modern, Elegant and Useful Designs. Sold by R. Sayer, London, 1755. Reimpreso en Research Publications, New Haven 1973.

-Select Architecture, Being Regular Designs of Plans and Elevations Well Suited to Both Town and Country. Prólogo de K. Placzek, Da Capo Press, New York, 1973.

MURPHY, James, Discourse on the Principles of Gothic Architecture. London, 1795.

NETTLETON, Thomas, Some Thoughts Concerning Virtue and Happiness. Printed for J. Batley, London, 1729.

-[Some Thougths Concerning Virtue and Happiness] A Treatise on Virtue and Happiness. ¿Edinburgh,? 1749.

Idem. $3^{\text {a }}$ ed. Printed for J. Payne \& J. Bouquet, London, 1751.

Idem. $6^{a}$ ed. Printed by Robert Urie, Glasgow 1751, 1759.

NEWBERY, John, The Art of Rhetorik. London, 1745.

-The Art of Poetry Made Easy. London, 1746.

-The Art of Poetry on a New Plan. 2 vols., London, 1762. 
NEWBURGH, B., Essays, Political, Moral and Critical. Dublin, 1769.

OGILVIE, John, Philosophical and Critical Observations on the Nature, Character and Various Species of Composition. London, 1774, 2 vols. Reimpresión en Garland Pu. Co, New York, 1970.

-An Essay on the Lyric Poetry of the Antients. 1762. Reimpresión en AMS Press, New York, 1992.

OLDMIXON, J., Essay on Criticism, as it Regards Design, Thought and Expression, in Prose and in Verse. Printed for J. Pemberton, London, 1728.

OVEREND, Marmaduke, A Brief Account of, and an Introduction to, Eight Lectures in the Science of Music. Printed for the Author and Sold by Mr. Payne and Son \& Mr. Thompsons, London, 1781.

PARNELL, Thomas, Essay on the Different Styles of Poetry. Printed by G. Grierson, Dublin, 1715.

PARSONS, J. W., Hints on Producing Genius. 1790.

PEMBERTON, Henry, Observations on Poetry, Specially on the Epic. London, 1738. Reimpresión en Garland Pub., New York, 1970, 167 págs. También en Thoemmes Press, London, 1994.

PENN, John, Letters on the Drama. Printed for Elmsly y otros, London, 1796.

- Critical, Poetical and Dramatic Works. Printed for Elmsly y otros, London, 1797.

PERCIVAL, Thomas, Moral and Literary Dissertations. Printed by W. Eyres en Warrington \& J. Johnson en London, 1784.

Idem. $2^{a}$ ed. 1789. Reimpresión en Garland Pu. Co, New York, 1971, 334 págs.

PINKERTON, John, Letters of Literature. Printed for G. G. J. \& J. Robinson, London, 1785.

POLIER Charles de, An Essay on the Pleasure Which Mind Receives From the Exercise of Its Faculties, and That of Taste in Particular, in Twenty Essays. Dublin, 1791.

POLWHELE, Richard, The Art of Eloquence: a Didactic Poem. Printed for C. Dilly, London, 1785-7.

-The English Orator. Printed for T. Cadell \& C. Dilly, London, 1786.

Idem. $3^{\mathrm{a}}$ ed. $1788,1789$.

POPE, Alexander ${ }^{9}$, Works. Ed. de W. Warburton, London, 1751.

-An Essay on Criticism. Edición, introducción y notas de S. L. Paul, Sidhartha Publications, Karnal 1988, 136 págs.

-An Essay on Man. Ed. de M. Mack, Methuen, London, 1982.

-The Art of Sinking in Poetry, 'Martinus Scriblerus' [Peribathous]. Edición crítica de E. L. Steeves, Russell \& Russell, New York, 1968, 207 págs.

-The Last and Greatest Art: Some Unpublished Poetical Manuscripts of Alexander Pope. Ed. de M. Mack, University of Delaware Press, Newark 1984, 454 págs.

9 R. H. Griffith, Alexander Pope. A Bibliography, Austin: University of Texas Press, 1922, 2 vols. Vid. también J.V. Guerinot, Pamphlet Attacks on Alexander Pope. A Descriptive Bibliography. Londres: Methuen, 1969. 
-The Works of Alexander Pope. Ed. de J. W. Croker. Introducción y notas de W. Elwin, Gordian Press, Nueva 1967, 10 vols. Reimpresión de la edición publicada en London, entre 1871-9.

PORTER, John, A Critical Essay Upon Epistolary and Elegiac Poetry en The Platonic Lovers. London, 1732.

POTT, Joseph, An Essay on Lansdcape, Painting etc. Printed by C. Etherington for J. Johnson, London, 1782,104 págs.

POTTER, John, Observations on the Present State of Music and Musicians. Printed for C. Henderson, London, 1762.

PRICE, Uvedale, An Essay on the Picturesque, as Compared With the Sublime and Beautiful. Vol. I. Printed for J. Robson, London, 1794.

Idem. Vol. I. A new edition. 1796.

Idem. Vol. II. Printed by D. Walker en Hereford \& J. Robson en London, 1798.

- Letter to H. Repton Esq. on the Application of... the Principles of Landscape Painting to Landscape Architecture. London, 1795.

PRIESTLEY, Joseph, Course of Lectures on Oratory and Criticism. Printed for J. Johnson, London, 1777.

Idem. Printed by W. Hallhead, Dublin, 1781.

-Observations on Style. Printed by H. Saunders, Dublin, 1763.

Idem. 1769.

- Hartley's Theory of the Human Mind. 1775.

PURSHOUSE, A., An Essay on Genius. Printed for the Author. Sold by Simmons \& Kirby en Canterbury y J. Dodsley en London, 1782.

PYE, Henry James, Beauty, a Poetical Essay. Printed for T. Becket \& P. A. de Hont, London, 1766.

- The Triumph of Fashion. A Vision. Printed for W. Griffin, London, 1771.

-The Progress of Refinement. A Poem. Clarendon Press, Oxford 1783.

- A Commentary Illustrating the Poetic of Aristotle. Printed for J. Stokdale, London, 1792.

-Sketches on Various Subjects, Moral, Literary and Political. Printed for J. Bell, London, 1796.

Idem. $2^{2}$ ed. 1797.

RALPH, Benjamin, The School of Raphael: or, the Students Guide to Expression in Historical Paintings. Printed for J. Boydell, London, 1759.

RAMSAY, Allan, A Dialogue on Taste en «The Investigator» 332 (1755).

RAY, John, Wisdom of God Manifested in the Works of the Creation. $6^{\mathrm{a}}$ ed., London, 1714.

REEVE, Clara, The Progress of Romance, Through Times, Countries and Manners. Printed for the Author by W. Keymer, Colchester 1785.

REID, Thomas ${ }^{10}$, An Inquiry into the Human Mind, or the Principles of Common Sense. Edinburgh, 1764.

10 R. Legum, "Bibliography of Thomas Reid" en The Monist LXI (1978), pp. 340-4. 
Idem. Edinburgh, 1765 y 1769.

Idem. London, 1785.

- Essays on the Intellectual Powers of Man. Printed for J. Bell \& G. G. J. en Edinburgh, y J. Robinson en London, 1785.

-Recherche sur l'entendement humaine. Amsterdam 1768, 2 vols.

-Untersuchungen über den menschlichen Geist. Leipzig 1782.

- Essays on the Intellectual Powers of Man. Garland Pu. Co., New York, 1971.

- Thomas Reid's Lectures on Natural Theology (1780). Ed. de E. H. Duncan. University Press of America, Washington 1981, 129 págs.

-Lectures on Fine Arts. Ed. de P. Kivy, M. Nijhoff, La Haya 1973.

- «Lecciones sobre las bellas artes», Estudio introductorio, traducción y notas de J.V. Arregui, en Contrastes 3 (1998), pp. 345-84.

REPTON, Humphry, Variety. A Collection of Essays. Printed for T. Cadell, London, 1788.

-The Bee, Or a Companion to Shakespeare Gallery. Printed for T. Cadell, London, ¿1789?

-Letter to Uvedale Price Esq. Printed for G. Nicol, London, 1794.

-Sketches of Hints on Landscape Gardening. Printed by W. Bulmer \& Co., London, 1795.

REYNOLDS, Frances, An Enquiry Concerning the Principles of Taste, and of the Origin of our Ideas of Beauty. Printed by Baker \& Galabain, London, 1785. Reimpresión en Garland Pu. Co., New York, 1972, 49 págs.

REYNOLDS, Sir Joshua, Discourses on Art. 1769-90.

-The Works of Sir Joshua Reynolds. Printed for T. Cadell \& W. Davis, London, 1797. Reimpresión en G. Olms, Hildesheim 1971, 2 vols.

Idem. $2^{\mathrm{a}}$. ed. 1798.

- Seven Discourses Delivered in the Royal Academy by the President. Printed by T. Cadell, London, 1778.

-Discourses. Edición, introducción y notas de P. Rogers, Penguin, London, 1992. 417 págs.

-Quince discursos. Poseidón, Buenos Aires 1943.

RICHARDS, George, An Essay on the Characteristic Differences Between Antient and Modern Poetry. Oxford 1789. RICHARDSON, Jonathan, An Essay on the Theory of Painting. Printed by W. Boyer
for J. Churchill, London, 1715 .

Idem. A. Bettesworth, London, 1725. Reimpresión en The Scholar Press, Menston 1971, 279 págs.

- A Discourse on the Dignity, Certainty, Pleasure and Adventage of the Science of a Connoisseur. Printed for W. Churchill, London, 1719.

-Two Discourses. I. An Essay on the Whole Art of Criticism. II. An Argument in Behalf of the Science of a Connoisseur. Printed for W. Churchill, London, 1719.

Idem. Printed for A. C. and Sold by A. Bettesworth. London, 1725.

-An Account of the Statues, Bas-Reliefs, Drawings and Pictures in Italy, France etc. Printed for J. Knapton, London, 1722. 
Idem. 1754.

- Explanatory Notes and Remarks on Milton's Paradise Lost. Printed for J. J. \& P. Knapton, London, 1725.

Idem. 1734.

-The Works of Jonathan Richardson. Containing I. The Theory of Painting. II. Essay on the Art of Criticism. III The Science of a Connoiseur. Printed for T. Davies, London, 1773. Reimpresión en G. Olms, Hildesheim 1969, 346 p.

Idem. $2^{\mathrm{x}}$ ed. Printed at Strawberry-Hill and Sold by T. \& J. Egerton, y otros, London, 1792.

RICHARDSON, William, A Philosophical Analysis and Illustration of Some of Shakespeare's Remarkable Characters. Printed for W. Creech, Edinburgh, 1774.

Idem. Printed for J. Murray en London, y W. Creech en Edinburgh, 1774.

Idem. $2^{2}$ ed. 1774.

Idem. A new edition. Printed for J. Murray, London, 1784. Reimpreso en AMS Press, New York, 1974.

ROBERTSON, Joseph, An Essay on the Nature of English Verse. London, 1799.

ROBERTSON, Thomas, An Inquiry into the Fine Arts. Printed for W. Strahan \& T. Cadell, London, 1784. Reimpresión en Garland Pu. Co., New York, 1971, 461 pags.

ROBINSON, Pollingrove, The Beauties of Painting. Printed for G. Robinson y otros, London, 1782.

ROBSON, William, Grammigraphia, or the Grammar of Drawing. Printed for the Author by W. Robson, London, 1799.

ROLLIN, Charles, The Method of Teaching and Studying Les Belles Lettres. 4 vols., London, $1742,3^{\text {a }}$ ed.

ROWLAND, Thomas, A General Treatise of Architecture in Seven Books. Printed H. Parker for the Author, London, 1732-39.

RUSSELL, John, Elements of Painting With Crayons. Printed for J. Wilkie \& J. Walker, London, 1772.

Idem. 1773, 1777.

RYLANDS, John, Select Essays on Moral Virtue, Genius, Science and Taste. 1792.

SCOTT, John Robert, An Essay on Painting to a Young Painter en Poetical Works. London, 1782.

SERLE, Ambrose, A Treatise on the Art of Writing. Printed for G. Keith, London, 1766. Idem. 1776, 1782.

SHAFTESBURY, Anthony Ashley Cooper, Earl of ${ }^{11}$, A Letter Concerning Enthusiam. Printed for J. Morphew, London, 1708.

-The Moralists. A Philosophical Rhapsody. Printed for John Wyat, London, 1709.

11 Puede encontrarse una bibliografía actualizada sobre Shaftesbury en la traducción de J. V. Arregui y P. Amau de A. A. C. Shaftesbury, Los moralistas. Barcelona: Ediciones Internacionales Universitarias, 1997. 
-Sensus Communis: an Essay on the Freedom of Wit and Humour. Printed for E. Sanger, 1709.

-Soliloquy: or, Advice to an Author. Printed for J. Morphew, London.

-Characteristicks of Men, Manners, Opinions and Times. 3 vols. 1711.

Idem. Printed by J. Derby, London, 1714, ¿1715?, 1723, 1727, 1732, 1733.

Idem. ¿Printed by J. Purser, London,? 1737-8.

Idem. ¿London,? 1743-5.

Idem. ¿London,? 1749.

Idem. Printed by J. Baskerville, Birmingham 1773.

Idem. Printed for J. J. Tourneisen \& J. L. Legrand, Basilea 1790.

Idem. ¿Printed by J. Darby, London,? 1711.

-A Notion of the Historical Draught or Tableture of the Judgment of Hercules According to Prodicus. London, 1713.

Idem. Printed for A. Baldwin, London, 1713.

- Several Letters Writen by a Noble Lord to a Young Man at the University. Printed for J. Roberts, London, 1716.

Idem. ¿London,?, 1732.

Idem. ¿London,?, 1790.

- Letters from the Right Honourable the Late Earl of Shaftesbury to Robert Molesmorth. Printed by W. Wilkins and Sold by J. Peele, London, 1721.

Idem. $2^{a}$, ed. 1721.

- Letters of the Earl of Shaftesbury, Author of the Characteristics, Collected into One Volume. 1746.

- Lettre de l'enthousiasme. Johnson, La Haya 1709.

—Essai sur l'usage de la raillerie. Henry Schleurleer, La Haya 1710.

-Principes de la philosophie morale ou essai de M. S. sur le mérite et la vertu. Amsterdam 1744.

Idem. Chatelain, París 1745. (Trad. de D. Diderot)

Idem. Venecia-París 1751.

-Les oeuvres de Mylord Comte of Shafiesbury contenant Les characteristiques etc., Ginebra 1769.

-Les soliloques. London y París 1771.

-Les conseils. París 1773.

- Les characteristics. Amsterdam y Leipzig 1780.

-Unterrendungen mit sich selbst. Magdeburg 1738.

-Die Sittenlehrer. Hauder und Spener, Berlín 1745.

-Soliloquium. Seidel und Scheidhauer, Magdeburg y Leipzig 1746.

-Untersuchunge über die Tugend. Berlín 1747.

-Entwurf der historischen Zeichnung, von dem Urteile des Herkules. Leipzig 1748.

-Aus den Anton Ulrich Grafen von Shaftesbury Characteristics. Tubinga 1753.

-Shaftesburys Selbsgresprach. Hamburgo 1767.

-Shaftesburys Characteristics. Leipzig 1767, 1768.

Idem. Leipzig 1776-9. 
Idem. Tubinga 1781.

-Letter Concerning Enthusiasm, and, Sensus Communis: an Essay on the Freedom of Wit and Humor. Ed. de R. B. Wolf, Garland Pu. Co., New York, 1988.

-Characteristics of Men, Manners, Opinions and Times, ed de J. M. Robertson, Gran Richards, London, 1900. Reeditado en The Bobbs-Merrill Co., Indianápolis 1964.

-Second Characters, or, the Language of Forms. Ed. de B. Rand, Cambridge University Press, Cambridge 1914. Reeditado en Greenwood Press, New York, 1969.

-The Life, Unpublished Letters, and Philosophical Regimen of Anthony, Earl of Shaftesbury. Ed. de B. Rand, S. Sonnenschein \& Co., London, 1900. Reeditado en Routledge and Kegan Paul/Thoemmes Press, London, 1992.

-Werke. Standard Edition. Fromman-Holzboog, Stuttgart 1981-93.

- Del soliloquio o Consejos al escritor. Introducción y traducción de D. A. Sampietro, Instituto de Filosofía, Universidad Nacional de la Plata, La Plata, 1962.

- Los moralistas. Traducción de D. A. Sampietro, Universidad Nacional de la Plata, La Plata, 1964.

- Sensus communis. Ensayo sobre la libertad de ingenio y de humor. Estudio introductorio, traducción y notas de A. Andreu, Pre-Textos, Valencia 1995.

- Carta sobre el entusiasmo. Introducción, traducción y notas de A. Andreu, Crítica, Barcelona, 1997.

-Investigación sobre la virtud y el mérito. Traducción de A. Andreu, CSIC, Madrid, 1997.

- Los moralistas. Traducción y estudio introductorio de J. V. Arregui y P. Arnau, Ediciones Internacionales Universitarias, Barcelona, 1997.

SHARPE, William, Dissertation upon Genius. Printed for C. Bathurst, London, 1755. Reimpreso en Scholars's Facsimiles and Reproductions, Delmar, New York, 1973.

SHERIDAN, Thomas, A Course of Lectures on Elocution: Together With Two Dissertations on Language. Printed by W. Straham y otros, London, 1762.

Idem. $2^{\mathrm{a}}$ ed. Printed for S. White. Dublin, 1764, 1770.

Idem. Printed for J. Dodsley, London, 1781, 1787, 1796, 1798.

Idem. Printed by Carter \& Wilkinson, Rhode Island 1797.

- Lectures on the Art of Reading. Printed for J. Dodsley, London, 1775.

Idem. 1781, 1787, 1794, 1798.

Idem. Printed for S. White, Dublin, 1782, 1790.

SMITH, Adam 12, Theory of Moral Sentiments. Printed for A. Millar en London, y A. Kinkaid \& J. Bell en Edinburgh, 1759.

Idem. $1767,1774,1781,1790$ y 1792.

12 Para la bibliografía sobre Adam Smith hasta 1950 puede verse B. Franklin y F. A. Cordasco, A Bibliographical Checklist. An International Record of Critical Writings and Scholarship Relating to Smith and Smithian Theory, 1986-1950. Nueva York: Burt Franklin, 1950. Para su actualización, véase C. Rodríguez Lluesma, La sociedad pasional. Adam Smith. Pamplona: Eunsa, 1997. 
Idem. A new ed. Printed and Sold by J. J. Tourneisen, Basilea 1793.

Idem. $8^{a}$ ed. Printed for A. Strahan, \& T. Cadell \& W. Davies en London, y for W.

Creech, \& J. Bell and Co. en Edinburgh, 1797.

-Essays on Philosophical Subjects. Printed for T. Cadell \& W. Davies en London, y W. Creech en Edinburgh, 1795.

Idem. Printed for Messrs. Wogan, Byrne, J. Moore, Colbert, Rice, y otros, Dublin, 1795. Idem. Printed for the Editor of the Collection of English Classics, Basilea 1799.

- Métaphysique de l'âme. Trad. de M. A. Eidous, París 1764.

-Theorie der moralischen Empfindungen. Trad. de G. Rautenberg, Brunswick 1770.

- Theorie des sentiments moraux. Trad. de l'Abbé Blavet, París 1774.

-Theorie der sittlichen Gefühle. Trad. de L. T. Kosegarten, Leipzig 1791-5, 2 vols.

-Essais philosophiques. Trad. de P. Prevost, París 1797.

-Theorie des sentiments moraux. Trad. de S. Grouchy y V. Condorcet, París 1798, 2 vols.

-Traducción castellana de la Teoría de los sentimientos morales. Por Alonso Ortiz. Valencia 1794.

- The Theory of Moral Sentiments. Edición de D. D. Raphael y A. L. Macfie, Clarendon Press, Oxford 1976.

-Teoría de los sentimientos morales, Traducción de C. Rodríguez Braun, Alianza, Madrid, 1997.

-Ensayos filosóficos, trad. de C. Rodríguez Braun, Pirámide, Madrid, 1998.

SMITH, Robert, Harmonics, or the Philosophy of Musical Sounds. Printed by J. Bentham, Cambridge y London, 1749.

Idem. $2^{\mathrm{a}}$ ed. Much improv'd and aument'd. 1759.

-A Postscript, to Dr Smith's Harmonics, upon the Changeable Harpsichord. Printed for T. \& J. Merrill \& B. Dod, Cambridge y London, 1778.

SOANE, John, Sketches in Architecture. Printed for I. Taylor, London, 1778.

Idem. 1790, 1793, 1797, 1798.

-Plans, Elevations and Sections of Buildings Executed in the Countries etc. Published by I. Taylor 1783 .

SPENCE, Joseph, Crito, or a Dialogue on Beauty. Printed for R. Dodsley, London, 1752. Reimpresión en Garland Pu. Co., New York, 1970, 61 págs.

Idem. $2^{\mathrm{a}}$ ed. 1752.

-Anecdotes, Observations, and Characters, of Books and Men Collected from Conversations. 1820.

Idem. $2^{x}$ ed., London, 1858.

-Observations, Anecdotes, and Characters of Books and Men, Collected from Conversation. Edición de J. M. Osborn, Clarendon Press, Oxford 1966, 2 vols.

STACK, Richard, An Essay on Sublimity of Writing. Transactions of the Royal Irish Academy, Dublin, 1787, I, 19-26.

STEDMAN, J., Laelius and Hortensia: or, Thoughts on the Nature and Objects of Taste and Genius. Printed for F. Balfour en Edinburgh, y T. Cadell en London, 1782. Reimpresión en Garland Pu. Co., New York, 1970, 536 págs. 
STEELE, Sir Richard, The Tender Husband, or, the Accomplishe'd Fools. A Comedy. Printed for Jacob Tonson, London, 1705.

Idem. With The Funeral. 1712, 1717.

Idem. Only The Tender, $5^{a}$ ed. 1731,1734 y 1735.

Idem. Printed by S. Powell, for George Risk, Dublin, 1740.

Idem. Printed for T. Lowndes, W. Owen, T. Caslon, W. Nicoll, S. Bladon \& W. Griffin, London, 1771.

Idem. Printed for John Bell en London, y C. Etherington en York, 1777.

Idem. Printed for Herrison and Co., London, 1779.

Idem. Printed for W. Lowndes, W. Owen, W. Nicoll, \& S. Bladon, London, 1787.

Idem. Printed by R. Butters, London, ¿1790?

Idem. Printed for the Propietators, under the Direction of J. Bell, London, 1791.

-On the Sublime en «Tatler» 43, 19 de Julio de 1709.

STEELE, Sir Richard (?), English Grammar With the Arts of Logic, Rhetoric and Poetry. London, 1728.

STEELE, Richard (no el ensayista), An Essay Upon Gardening. Printed for the Author by G. Peacok, York 1793.

STEWARD, Dugald, Elements of the Philosophy of the Human Mind. 3 vols. Printed for A. Strahan \& T. Cadell en London, y W. Creech en Edinburgh, 1792-1827.

-Anfangsgrunde der Philosophie über die menschl. Steele. Trad. de S.G. Lange, Berlín 1794.

STILES, Sir Francis Haskins Eyles, An Explanation of the Modes in the Antient Graecian Music... Read at Several Meetings of the Royal Society. London, 1761.

STILLINGFLEET, Benjamin, The Principles and Power of Harmony. Printed by J. \& H. Hughs, London, 1771.

STIRLING, John, A System of Rhetoric. London, 1733.

STOCDALE, Percival, An Inquiry into the Nature and Genuine Laws of Poetry Including a Particular Defence of the Writings and Genius of Mr. Pope. Printed for N. Conan, London, 1778.

STUART, James, Critical Observations on the Buildings and Improvements of London. Printed for J. Dodsley, London, 1771.

STUART, James y REVETT, Nicholas, The Antiquities of Athens Measured and Delineated. Printed by J. Haberkorn, London, 1762.

STUBBES, George, A Dialogue on Beauty. Printed by W. Wilkins, London, 1731. Reimpresión en Garland Pu. Co, New York, 1970, 55 págs.

SWIFT, Jonathan, On Poetry: a Rhapsody. Sold by J. Huggonson, Dublin, y London, 1733.

SWITZER, Stephen, The Country Gentleman's Companion. Printed for T. Astley, London, 1732.

-Ichonographia Rustica. 3 vols. Printed for B. Barker \& C. King, London, 1715. Idem. 1717, 1718, 1742.

TAYLOR, Brook, Linear Perspective: or a New Method of Representing Justly All Manner of Objects as They Appear to the Eye. Printed for R. Knaplock, London, 1715. 
- New Principles of Linear Perspective. Printed for R. Knaplock, London, 1719.

Idem. $3^{a}$ ed. Corrected and Augmented by J. Colson. Printed for J. Ward, London, 1749.

TEMPLE, Sir William, Miscellanea I. $5^{\mathrm{a}}$. ed. Printed and Sold by the Booksellers of London, and Westminster, 1709.

- Miscellanea III. Printed for Benjamin Tooke, London, 1701.

- Essays on Ancient and Modern Learning and on Poetry.

-The Works of Sir William Temple. Greenwood Press, New York, 1968, 4 vols.

-Essays on Ancient and Modern Learning and on Poetry. Edición de J. E. Spingarn, Folcroft Press, Folcroft, Pa. 1970, 88 págs.

THOMSON, Alexander, The Paradise of Taste. Printed for T. Cadell \& W. Davis, London, 1796.

-Pictures of Poetry. Printed for Mudell \& Longman, Edinburgh, y London, 1799.

THOMSON, James, The Seasons. Printed for J. \& A. Millar, London, 1730.

-62 ediciones a lo largo del siglo.

TICKLE, Richard, The Wreath of Fashion or the Art of Sentimental Poetry. London, 1778.

TRAPP, Joseph, Praelectiones poeticae. Printed for B. Lintott, London, 1711-9.

- Lectures on Poetry Read in the Schools of Natural Philosophy at Oxford. Printed for C. Hitch \& C. Davis, London, 1742. Reimpresión en G. Olms, Hildesheim 1969. También en Thoemmes Press, London, 1994.

TRENCHARD, John, The Natural History of Superstition. Sold by A. Baldwin at Oxford Arms in Warnick Lane, London, 1709.

TRYDELL, John, Two Essays on the Theory and Practice of Music. Printed for the Author by B. Grierson, Dublin, 1766.

TUCKER, Abraham, The Light of Nature Pursued. Printed by T. Jones, London, 1768.

TURNBULL, George, Principles of Moral Philosophy. Printed for the Author and Sold by A. Millar, London, 1740. Reimpresión en G. Olms, Hildesheim 1976, 2 vols.

-A Treatise on Ancient Painting. London, 1740. Reimpresión en W. Fink, Munich 1971, 193 págs.

TURNER, William, Sound Anatomized in a Philosophical Essay on Music. Printed by W. Pearson for the Author, London, 1724.

Idem. $3^{a}$ ed. Printed for J. Walsh, London, 1740.

TWINING, Thomas, Aristotle's Treatise on Poetry, Translated With Notes and Two Dissertations on Poetical and Musical lmitation. 2 vols. 1789.

USHER, James, Clio: or a Discourse on Taste. Printed for T. Davies, London, 1767. Idem. 1769 y 1772.

Idem. Printed for John Millik, Dublin, 1770.

VINCENT, William, Considerations on Parochial Music. Printed for T. Cadell, London, 1787. Idem. 1790.

WALCOTT, D., Observations on the Correspondence Between Poetry and Music. 1769.

WALKER, A., Beauty, Illustrated Chiefly by an Analysis and Classification of Beauty in Women. Printed for E. Wilson, London, 1736. 
WALKER, John, Elements of Elocution. Printed by T. Cooper \& Wilson, London, 1779,2 vols.

Idem. Printed for the Author and Sold by T. Cadell y otros, London, 1781.

- Hints for Improvement in the Art of Reading. Printed for the Author and Sold by T. Cadell y otros, London, 1783.

-A Rhetorical Grammar. Printed for the Author and Sold by G. Robinson, London, 1785.

Idem. 1787.

-The Melody of Speaking Delineated, or, Elocution Taught Like Music by Visible Signs. Printed for the Author and Sold by G. G. J., J. Robinson \& otros, London, 1787.

WALWYN, B., An Essay on Comedy. Printed for M. Hookman y otros, London, 1782.

WARD, John, A System of Oratory. Printed for the Author, London, 1759, 2 vols.

WARTON, Joseph, The Enthusiast, or Lover of Nature. A Poem. Printed for R. Dodsley, London, 1744.

-Odes on Several Subjects. 1746.

-The Adventurer 80 ( 2 de agosto de 1753).

-Essay on the Writings and Genius of Pope. Printed for M. Cooper, London, 1756. Reimpreso en Garland Pu. Co, New York, 1974, en unión con el segundo volumen publicado en 1782 .

Idem. Printed for R. \& J. Dodsley, London, 1762, 1772 y 1782.

Idem. Printed for P. Wilson, Dublin, 1764.

WATTS, Isaac, Logic. $2^{2}$ ed. Printed for J. Clarke \& R. Hett, E. Mathews, \& R. Ford, London, 1726. Reimpreso en Garland Pu. Co., New York, 1984, 365 págs.

Idem. $3^{\mathrm{a}}$ ed. 1729.

Idem. Printed for E. Mathews, R. Ford, \& R. Hett, London, 1731, 1733, 1736 y 1740

Idem. $11^{2}$ ed. Printed for J. Waugh, J. Ward, J. Buckland, T. Longman, W. Fenner \& E. Dilly, London, 1760.

Idem. $14^{a}$ ed. Printed for J. Buckland \& T. Longman, E. \& C. Dilly, \& T. Field, London, $1768,1772,1782,1786$ y 1790.

Idem. Sold by T. Davidson, R. Thomson \& D. Manson, London, i1755?

Idem. A new edition. Printed for J. Dickson, \& J. \& J. Fairbairn, Edinburgh, 1792.

Idem. A new edition. Printed for J. Binns, Leeds 1792.

Idem. A new edition. Printed for W. Phorson \& B. Law and Son, London, 1793.

Idem. Printed for A. Millar, W. Cater \& G. Robson, London, 1797.

-Improvement of the Mind. Printed for J. Brakstone, London, 1741.

Idem. 1743, 1753, 1782, 1785, 1786 y 1787.

Idem. Printed by J. Lamson \& T. Odione en Exeter, New Hampshire, y por D. West en Boston, 1793.

Idem. Printed for T. Longman, C. Dilly, F. \& C. Rivington, W. Goldsmith, D. Ogilby \& J. Speare, London, 1795.

- Miscellaneous Thoughts. Printed for R. Ford at the Angel \& R. Hett at the Bible, Poultry 1734. Reimpresión en Garland Pu. Co., New York, 1971, 350 págs. 
WEBB, Daniel, Observations on the Correspondence Between Poetry and Music. Printed for J. Dodsley, London, 1769. Reimpresión en Garland Pu. Co., New York, 1970, 155 págs.

-Remarks on the Beauties of Poetry. Printed for R. \& J. Dodsley, London, 1762. Reimpresión en Garland Pu. Co., New York, 1970, 123 págs.

Idem. Printed by S. Cotter, Dublin, 1764.

-An Inquiry into the Beauties of Painting, and Into the Merits of the Most Celebrated Painters, Ancient and Modern. Printed for R. \& J. Dodsley, London, 1760.

Idem. $2^{2}$ ed. 1761,1769 y 1777.

Idem. Printed by S. Cotter, Dublin, 1764.

WEEKES, N., On the Abuse of Poetry. A Satyre. Printed for R. Manby, London, 1752. Idem. 1754

WEST, Benjamin, Sacra Concerto: or the Voice of Melody. Containing an Introduction to the Grounds of Music.

WHATELY, Thomas, Remarks on Some of the Characters of Shakespeare. Printed for T. Payne and Son, London, 1785.

WHITEHEAD, William, An Essay on Ridicule, Printed for R. Dodsley, London, 1743.

WHITER, Walter, A Specimen of Commentary on Shakespeare: Containing an Attempt to Explain and Illustrate Various Passages in a New Principle of Criticism, Derived from Mr. Locke's Doctrine of the Association of Ideas. Printed for T. Cadell, London, 1794. Reimpresión en Garland Pu. Co., New York, 1970, 258 págs.

WOOD, John, The Origin of Buildings: or the Plagiarism of the Heathens Detected. In Five Books. Printed by S. \& F. Farley, London, 1741.

-A Dissertation Upon the Order of Columns, and Their Appendiges. Printed by J. Bettenham, London, 1750.

-A Series of Plans for Cottages or Habitations of the Labourer. Printed for I. \& J. Taylor, London, 1792.

WOOD, John (Master of the Drawing Academy, Edinburgh,), Elements of Perspective... With Its Application to Architecture. Printed for and Sold by A. Guthrie, Edinburgh, 1799.

WOOD, Robert, Essay on the Original Genius and Writings of Homer. Printed for $\mathrm{H}$. Hughs, T. Payne \& P. Elmsly, London, 1775. Reimpreso en McGrath Pu. Co., Washington 1973, 342 págs.

Idem. Printed for W. Hallhead, Dublin, 1776.

Idem. Seven Copies Privately Printed, London, 1769.

YOUNG, Edward, Conjectures on Original Composition. Printed for A. Millar, London, 1759.

—On Lyrick Poetry. 1728.

-The Complete Works, Poetry and Prose. Ed. de J. Nichols, London, 1854, 2 vols. Reimpreso en G. Olms, Hildesheim 1968. 
Jorge V. Arregui es profesor titular de Filosofía en la Universidad de Málaga. Es traductor al castellano de los escritos estéticos de Shaftesbury, Hutcheson y Reid, sobre los que ha publicado diversos trabajos.

Dirección postal: Departamento de Filosofía, Facultad de Filosofía y Letras, Universidad de Málaga, 29071 Málaga

E-mail: jvarregui@airtel.net

Pablo Amau es doctor en Filosofia por la Universidad de Valencia y profesor de Enseñanza Secundaria. Ha publicado artículos osbre estética británica del siglo XVIII así como sobre el problema del relativismo y el pensamiento de Collingwood.

Dirección postal: Aptdo. 77. 1280 Benicarló. 